$T X$ 551 $-K 4$

sided

M.x.

1. By 


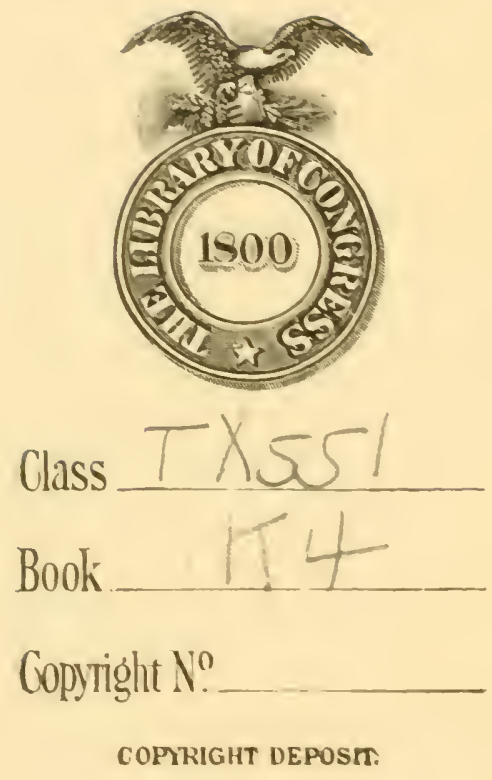






\section{A TREATISE ON \\ FOOD AND EGG PRODUCTION.}

BY FREDERICK KELLEY. 


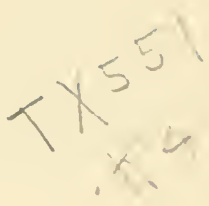

\begin{tabular}{l} 
LIBRARY of CUNGRESS \\
Two CoDies Recelved \\
FEB 231809 \\
Copyrimnt Entry \\
Jeb. 8,1909 \\
CLASS 19 xxa No. \\
230282 \\
\hline COPY 8.
\end{tabular}

COPYRIGHT, 1909, BY FREDERICK KELLEY. 


\section{INTRODLCTORY REMARKS ON THE DINAMIC RELATIONS OF FOOD.}

All food comes primarily from the vegetable kingdom, and regetable products are built up through the agency of the sun's rays. It may be said that the energy contained in these rays, which has been employed in producing the compound, is fixed or rendered latent within it. The formation of regetable products is coincident with the disengagement of oxygen from oxidized principles and the derelopment of combustible compounds. To effect this disengagement the operation of force is required. Norr, the force so employed has its source in the heat and light evolved from the sun, and that which is used for the purpose may be said to become fixed and to exist in a latent condition-to exist stored up in the product, ready to be again liberated on exposure to conditions farorable to oxidation. Thus these regetable products contain a store of latent force, which may for an indefinite period remain as such, or may be liberated soon after it has been fixed. Whenever liberated, it is no more nor less than the equivalent of the force which has been used in the formation of the product. Our coal fields represent a rast magazine of force drawn, ages ago, from the sun's rays, and capable at any moment of being set free by the occurrence of oxidation. 
Tegetable products, then, may be regarded as containing a store of force accumulated from the rast supply continually emitted with the sun's rays; and, upon the principle of the indestructibility of force, that force which has been applied to mnlocking the elements in the combinations from which regetable products are built up, and to forming the new compound, is contained in such compound in a latent state. Now, animals either directly or indirectly subsist upon these regetable products, and are thence supplied by them with accumulated force. By oxidation the force is set free in an active state under some form of manifestation or other. It matters not in what way-whether rapidly or slowly, or under what circumstances-whether inside or outsicle the living system, the oxidation occurs: the result is the same, as far as the amount of the force liberated is concernecl-it constitutes the equiralent of the solar force originally made use of.

Thus it is that the various forms of force manifested in the actions of animal life trace their origin to that enitted from the sum. Plants are media for fixing solar force-for converting actual into latent or potential energy. Animals reconvert latent into various forms of actual force. Thus, in the various forms of actual force liberated by the actions of animal life, we have the equivalent of that which has been fixed by plants from the sun. As there is a revolution of matter, so is there a revolution of force within and around us.

In the animal system, combustible material is supplied under the form of the rarious kinds of food, and oxygen is taken in by the process of respiration or breathing. 
From the chemical energy due to the combination of these, force is liberated in an active state: and besides manifesting itself as heat, and in other ways peculiar to the animal system, is capable of performing mechanical work. According to the most reliable authorities, the animal economy, in respect of its capacity to turn force to account in the accomplishment of mechanical work, is a more perfect instrunlent than a stean-engine. 111 calculations learl to the conclusion that while in the steamengine only about a tenth of the force liberated by the combustion of its fuel is realizable as mechanical work, the rest escaping as heat, the human body is capable of turning at least a fifth of the power of its food into the equiralent of work. However, there is this in faror of the stean engine--its fuel is far less expensive than the food of an animal being.

The animal body, then, may be regarded as hoiding an analogous position to a machine, in which a transmutation of chemical into other forms of force is taking place. Food on the one hand, and air on the other, are the factors concerner in the chemical action that occurs. It is the changes between food and air wherein the manifestations of animal life, consisting of heat production, muscular contraction, nerrous (inclucling mental) action, and nutritive or formative, secretory, and assimilative action arise. The substances thrown ont or dismissed from the system are merely changed products of what was taken into the system. The elements are the same, in nature and in quantity, in the two cases, but their forms of combinations, and, with them their force accompaniment, are different. The force employed in 
building up the organic compounds belonging to food is again evolved as they descend by oxidation into more simple combinations, and in the force evolved we have the representative of the active manifestations of animal life.

What is required in food is matter that is susceptible of undergoing change in the system under the influence of the presence of oxygen. Life implies change, and the manifestations of life are due to the reaction of food, with the derivatives from it, and air upon each other. While in the inorganic kingdom a tendency to a state of rest prevails-while the closest affinities tend to become satisfied, and so balance each the other, in a manifestly living body rest is impossible. It is true, living organisms of certain kinds may exist in a state of rest, but then there is a suspension of vital manifestations. The state constitutes that which is properly denominated "dormant vitality." Animal organisms may exist in it, and the seed of a plant naturally remains for awhile in it. The molecules rest, and there is an absence of any show of vital activity prevailing. Concurrently a change is a particular direction occurs. Organic compounds become resolved by the agency of oxygen into more simple combinations, as carbonic acid, water, and urea, and are no longer of any service. To maintain a continuance of vital activity fresh organic material is required; hence the demand for food. But food and the other material factor of life-oxygen-do not constitute all that is needed. It is further necessary that the two should be brought within the sphere of influence of living matter, in order that the changes may be made to pursue the particular line of direction resulting in the phenomena of life. 


\section{FOOD.}

\section{CONSTITUENT ELEMENTS OF FOOD}

Of the various elements known to exist in nature only a limited number enter into the constitution of living bodies. The following is a list of those found as constituents of the human body. The first four, viz., carbon, hydrogen, oxygen, and nitrogen, exist in far larger quantity than any of the others. As for those which occur towards the end of the list, they are present only in minute quantity, if, indeed, they are invariably present. It is more than doubtful if they are to be regarded as essential constituents.

Carbon, Hydrogen,

Oxygen,

Nitrogen,

Sulphur,

Phosphorus,

Chlorine,

Sodium,

Potassiun11,

Calcium,

Magnesium,

Iron,

Fluorine,

Silicon,

Manganese,

Aluminium,

- Copper.

The food being the source from which the elements forming the constituents of the body are derived, it 
follows that food must contain all the elements which are there met with. No article can, as food, satisfy the requirements of life that fails to comply with this condition.

\section{ALIMENTARY PRINCIPLES.}

Although it is necessary that our food should contain the elements that have been enumerated-and contain them in such proportion as to furnish the requisite amount of each to the system-yet it is not with these elements as such that, from an alimentary point of view, we have to deal. It is only in a state of combination that the elements are of any service to us as food; and, as has been already mentioned, the combination must have been formed by the agency of a living organism-the combination must, in other words, constitute an organic product.

In a scientific consideration of food it is necessary to speak first of the alimentary principles. It is only, indeed, by looking at it through its constituent principles that we are in position to discuss its after effects. Popularly, what we eat and take in consist of food and drink, the one supplying us with solid, the other with liquid matter. From a physiological point of view this is worthless. "Food" and "drink" constitute terms referring only to the particular state in which an article for consumption may happen to exist-whether it is in a solid or a liquid form. What is drunk, for instance, and this is particularly true of milk, may be rich in food, or solid matter, and in the food we consume there is invariably a large proportion of liquid matter. 
The two material factors of life are food and air: and food may be considered as comprising that which contributes to the growth and nutrition of the body, and, by oxidation, to force-production. Regarded in this connprehensive light, food embraces both solid and liquid matter; and the primary natural division is into organic and inorganic portions--that is, combinations of elements producible only through the agency of life; and cliemical combinations drawn simply from the mineral kingdom and incorporated with the others.

The inorganic portion of food consists of water and various saline principles. The organic portion may be subdivided into compounds of which nitrogen forms a constituent, and compounds from which it is absent; in other words, into nitrogenized and non-nitrogenized compounds. The non-nitrogenized alimentary principles are composed of three elements-carbon, oxygen and hydro-. gen, variously mited together, while the nitrogenized likewise contain these three elements, but, in addition, nitrogen; and, for the most part. sulphur, or sulphur and phosphorus as well. It stands to reason that for the growth and repair of the rarious textures of the body. as these have nitrogen forming an essential ingredient of their constitution, nitrogenized compounds must be supplied; but, these compounds are likewise susceptible of anplication to heat production. They are truly tissueformin materials, but. by the separation of some waste matter a compound is left, which may be appropriated to heat production. It may be asserted that there is sutficient to show that the nitrogenized principles in reality subserve both purposes in the animal economy. 
In fat. again. we have a non-nitrogenous principle. and one belonging: therefore. to the heat producing group. There is every reason to believe, however. that fat is essential to tissue derelopment. It seems to be intrinsically mixed up with nitrogenized matter in the animal textures. Certainly. it may be said to be directly applied towards the formation of adipose tissue. Fat. therefore, takes rank as a nutrient no less than as a heat producing food. Fats are also concerned in muscular torce-production.

Some authorities classify food in sereral groups of principles such as:

Aqueous,

Saccharine,

Oily,

Albunininous,

Saline.

The saccharine and oil groups comprise non-nitrogenized principles, while the albuminous comprehends the nitrogenized.

Food falls naturally into-

Organic, and

Inorganic, divisions.

Nert the organic is subdivisible into-

Nitrogenous, and

Non-nitrogenous:

and further that the non-nitrogenous is naturally and conveniently again subdivisible into-

Fats and

Carbohydrates; 
the former consisting of carbon and hydrogen in combination with only a small amount of oxygen; the latter of carbon with oxygen and hydrogen always in such relation to each other as to be in the exact proportion to form water. To this latter group belong such as starch, sugar, gum, etc. It must be observed that there are a few principles which do not strictly fall within either of the preceding groups. Such, for instance, as alcohol, the regetable acids, and pectin or regetable jelly. Alcohol occupies an internediate place between the fats and carbolyydrates, while the others are even more oxidized compounds than the carbohydrates - in other words, contain a larger amount of oxygen than is required for the conversion of their hydrogen into water. These principles are hardly of sufficient importance, in an alimentary point of view, to call for their consideration nnder a distinct head, and are generally spoken of in connection with the carbohyclrates.

\section{NITROGENOUS ALIMENTARY PRINCIPLES.}

Nitrogen enters largely into the composition of the animal body. It therefore requires to be freely supplied from without. Although living in an atmosphere about four-fifths of which consist of nitrogen, yet it is not from this source (though that idea was once entertained), that our supply of nitrogen is obtained. Nitrogen, to be arailable for us, must be supplied in a state of combination. It is not, indeed, with nitrogen in the form of an element that we have anything to do in the question of alimentation, but only with compounds containing it, and such compounds, it may be said, that have been produced 
under the influence of life-that is. compounds which answer to the name of "organic."

Organic nitrogenous matter, then, and not Nitrogen, is what we require to have supplied to $u s$. and what alone we have to deal with here. Such nitrogenous matter must. therefore. constitute an essential ingredient of our food, and we find that it there exists moler rarious chemical forms. If we look at the nitrogenized alimentary principles which hare been macle hnown, some are characterized by yielding protein when subjected to the action of an alliali and heat. while from others no protein is similarly to be procured. The former comprise the allouminous group. and are often referred to as the protein compounds: the latter constitute the gelatinous principles.

Whe' Mulder first discorered protein, the substance was regarded as forming the base of the albuminous principles. It contains the iour elenents-carbon. hrodrogen, oxIgen and nitrogen: and eacl of tine albuminous principles was regarded as simply resulting from the combination of the supposed hase with different quantities of sulphur and phosphorus, or sulphur only. It must be stated. howerer. that there is nothing to show that protein really exists in the componnds from which it is to be cbtained. It can be regarded only as a product of the chemical process to which it is necessary to subject the compounds to obtain it. It serves, howerer. to link together certain important physiological compounds.

- flbun:an may be looked upon as the most important representative of the protein group. It consists of four elements-carbon, oxygen. hydrogen and nitrogen. with the addition of some sulphur and phosphorus. As it is 
met with in animal productions, it is in such intimate minion with fatty, alkaline, and earthy matter, that it is with some difficulty separable from them. It varies to some extent in its behavior, as it is obtained from different sontces. The albumen of the blood, for instance, does not agree in all respects with the albumen of the white of the egg. One of the most striking properties of albumen is its coagulability upon the application of heat. It, therefore, exists under two states, viz., soluble and coagulated albumen. That albumen can afford the nitrogenous matter required for nutrition is proved by its being the principle in the egg from which are developed the nitrogenous tissues of the chick.

Casein forms the protein compound of milk. It is distinguishable from albumen by not being coagulable by heat, and by being thrown down by organic acids which do not precipitate albumen. Besides the four elements-carbon, oxy̆gen, hydrogen and nitrogen-it contains sulphur, but no phosphorus.

Tegetable Albumen is contained in wheat and the other seeds of the Cerealia. The juices of most regetables, such as turnips, carrots, cauliflower, cabbage, etc., yield more or less precipitate with heat by virtue of its presence. It is also found in considerable abundance in association with regetable casein in the oily seeds, such as almonds, nutts, etc.

Tegetable Cascin can be obtained from peas, beans, and other leguminous seeds, and is sometimes specially denominated legumin. It also exists, with albumen, in the almond and such like oily seeds. 
Gelatinous Principles constitute nitrogenous compounds, but do not yield protein like the compounds that have just been referred to. They comprise gelatin and chondrin, and are obtainable only from animal products; gelatin from bone and other structures containing fibrous tissue. and chondrin from cartilage. The most striking property they possess is that of their watery solution gelatinizing upon cooling. It is gelatin which forms the basis of soups. Besides carbon, hydrogen, oxygen and nitrogen. as constituent elements, a small amount of sulphur appears also to be present. They contain no phosphorus.

Now, it has been stated that the gelatinous principles which have fallen under consideration are to be obtained only from animal products. No nitrogenous compound of the kind is met with in regetable materials. The jelly yielded by fruits and some other regetable substances is quite a different article. It consists only of the three elements-carbon, hydrogen and oxygen, and is known chemically as pectin or pectic acid.

All the nitrogenous principles must undergo digestion before they can enter the system. Digestion, in fact, is simply a process which has for its object to fit substances for absorption into the system; and the nitrogenous principles are in a state to resist absorption, until they have been liquified and transformed by the agency of digestion.

\section{NON-NITROGENOUS ALINENTARY PRINCIPLES.}

While nitrogenous matter may be regarded as forming the essential basis of structures possessing active or 
living properties, the non-nitrogenous principles may be looked upon as supplying the source of power. The one may be spoken of as holding the position of the instrument of action, while the other supplies the motive power. Nitrogenous alimentary matter may, it is true, by oxidation contribute to the generation of the moring force. but, in fulfilling this office it is evident that it is split up into two distinct portions, one containing the nitrogen which is eliminated as useless, and a residuary nonnitrogenous portion which is retained and utilized in force-production. It is true also that non-nitrogenous natter may be applied to tissue formation, but it is probable that, in doing so, it is simply for the purpose of being stored up for subsequent appropriation to forceprodiction, according as circumstances may require.

The non-nitrogeneous alimentary principles comprise:

Ist. The hydrocarbons or fats;

2nd. The carbohydrates, starch, sugar, etc, and

3rd. Principles such as alcohol not falling strictly within either preceding group.

Hydrocarbons or Fats. These principles constitute compounds consisting of carbon and hydrogen, combined with only a small proportion of oxygen. Represented in round numbers, the following may be given as the percentage composition of the chief fatty principles:

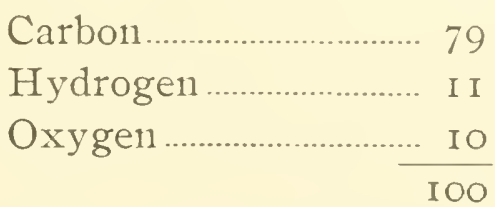

Fats are supplied to us in both animal and regetable articles of food. The digestion of fat takes place in the 
small intcstine. It traverses the mouth without molergoing any change beyond that induced by the mechanical action of mastication. As regards animal and regetable fats, it appears that the former are easier of digestion and absorption than the latter. A given quantity of fat will derelop more than trice as much heat in the process of oxiclation as the same quantity of starch. The actual heat expressed in units:

Beef fat,

Starch,

Cane sugar,

Commercial grape-sugar, 33
90 heat units

39

34

Looking at this clifference in the relative value of fatty, starchy and saccharine matters as heat-producers, we see the wisclom of the instinctive consumption of food abounding in fatty matter by the inhabitants of the Arctic regions. The Esquimatux and other dwellers in the cold zone derour sreedily the fat of whales, seals, etc., and find in this the most efficient kind of combustible material. In the tropics, on the other hand, the food consumed by the native inluabitants consists mainly of farinaceous and succulent regetable matter. On account of the high temperature of the surrounding air less heat is required to be produced within the body, and a less efficient combustible material is able to supply what is needed for the maintenance of the ordinary temperature.

\section{THE CARBOHYDRATES.}

The Carbohydrates forming a second systematic group of non-nitrogenous alimentary principles, are compounds in which the hydrogen and oxygen exist in the proportion 
to form water. Hence these compounds have been designated hydrates of carbon or carbohydrates. It must not, however, be inferred that the elements are in reality grouped as the name would imply. There is no ground for such a conclusion. All that can be said is that the respective quantities of the elements are such as would form water. But from this it does not follow that they exist in combination as water, to be then linked as such to the carbon. Comprised in the group of compounds we have:

Starch,

Cane-sugar,

Grape-sugar,

Sugar of milk (lactin),

Amyloid substance,

Gum,

Dextrin,

Cellulose,

Woody fibre,

Lactic acid,

Acetic acid.

Starch may be regarded as the most important of the group, on account of its entering so largely as it does into sonie of our staple articles of food. It is met with only in vegetable products, and is found stored up in the form of little granules, or solid particles, in many seeds, roots, stems, and some fruits. In cold water the granules remain unaltered, but when subjected to the influence of boiling water they swell up, burst, and form a mucilage which assumes a gelatinous nature on being allowed to cool. 
Cane Sugar. There are various kinds of sugar, and this is the crystallizable variety, which is so extensively employed as an article of food. It is produced only by the regetable kingdom, and is contained in the juice of the stems, roots, and other parts of various plants. It is present in a dissolved state in these juices instead of existing in a solid form, as is the case with starch.

Grape Sugar. is met with extensively as a regetable product in the juices of many fruits and other parts of plants, and is also readily obtainable from other carbohydrates by chemical means, and likewise by the influence of organic bodies in a state of change. It may, perhaps, be set down as representing the lowest of the neutral compounds of the carbohydrate group, as it constitutes that form into which they are all easily convertible, and into which they appear to have a tendency to descend. It is a substance which requires no preliminary process of digestion to fit it for absorption, and it may be considered that the main part of that which is received into the alimentary canal passes without modification into the blood ressels, by virtue of the physical property of diffusibility which it enjoys.

Gum, like starch, extensively pervades the vegetable kingdom. It is met with in the juices of nearly all plants, and occurs in its purest form as an exudation upon the bark of certain trees. With water it produces a tasteless, ropy liquid strongly adhesive. Gum is convertible into sugar by boiling with dilute sulphuric acid.

Ccllulose. This constitutes the basis of the structure forming the walls of the cells, fibres, and ressels of plants. It is presented in a nearly pure form in cotton, linen, and 
elder pith. It offers strong resistance to solution, but yields, however, to the more powerful chemical agents.

It may be said here that the carbohydrates conduce to the production of fat because:

1st. Certainly a large portion of the fat of the herbivora fattened for human food nutust be derived from other substances than fatty matter in the food.

2nd. When fattening animals are fed upon their most appropriate food, much of their stored-up fat must be produced from the carbohydrates it supplies.

3rd. Nitrogenous substances may also serve as a source of fat. more especially when it is in excess, and the supply of available non-nitrogenous constituents is relatively defective.

\section{INORGANIC ALIMENTARY PRINCIPLES.}

Altholigh it is to the changes taking place in organic matter that the manifestations of life are to be traced, yet organic matter alone, it has been found, will not suffice for supplying all that is wanted for the occurrence of living action. Inorganic matter, under the form of water and certain saline principles, constitutes an indispensable part of a living being, and hence must enter into the composition of food.

Water, besides fulfilling many other subsidiary offices, is essential for the occurrence of molectular change or mobility-the essence of the manifestations of life. In the absence of water, a state of molecular rest which means an absence of vital activity prevails. Water does not in itself undergo any chemical alteration, and hence is not susceptible of liberating force-does not, in other 
words, constitute a force-producing agent, but it contributes to chemical change by supplying a necessary condition for its occurrence in other bodies.

Saline matter stands, if not to the full extent, nearly so, in the same position as water as regards the nonpossession in itself of force-producing properties. Some of the saline matter of food, it is true, may be susceptible of oxidation, and thereby give rise to the liberation of force, but this, it nuay be considered, is not the particular cffice which saline matter is designed to fill. It forms a necessary part of the organism, without, however. constituting the source of the manifestation of porrer. It exists intimately incorporated with the organic principles comprising the different component parts of the fabric, and enters as an essential element into the constitution of the secretions.

Mineral matter is thus required to be furnished for the growth and nutrition of the constituent parts of the organism, and also for the formation of the secretions. It is required by the plant as well as by the animal, and hence we find in all natural organic products a certain admixture of mineral matter. It hereby follows that whether the food be derived from the animal or the vegetable kingdom, there exists, entering into its constitution, a definite proportion of mineral matter; and, just such as is required by the animal being has been drawn from the inorganic kingdom by the plant, whereby, without going further than the organic substance itself, the animal meets with the mineral matter that is needed.

Of the various saline principles necessary, the chief consist of combinations of lime, magnesia, potash, sodit, 
and iron, with chlorine, phosphoric acid, carbonic acid, and in smaller quantity, sulphuric acid. Each has its share of importance, but lime and phosphoric acid may be looked upon as ocupying the highest position in this respect. From no structural element of the body is phosphate of linne, it would appear, absent, and its incorporation with the nitrogenous constituent principles is so intimate that much difficulty is experienced in effecting a complete separation without involving the destruction of the compound. Casein is a nitrogenous principle which is conspicuous for the tenacity with which it holds a large quantity of phosphate of lime incorporated with it. From what is observed, indeed, in the relations of the organic and mineral principles to each other, it seems that in many instances an actual chemical minion of the two exist.

That the various kinds of saline matter must fulfil a specific office in the econonny of life may be looked upon as shown, if proof of it, were wanted, by the special manner in which it is distributed.

Although so closely allied in their chemical properties, potash and soda cannot be made to replace each other in the living system, and the same is likewise noticeable in the case of lime and magnesia. In the process of regetable alimentation a qualitative and quantitative selection is made by the organism from the soil around. While in some plants one kind of mineral nutter may predominate, in others it may be another kind, and to such an extent may this preponderance reach as to have led to plants being characterized as potash plants, lime plants, siliceous plants, añd so on. In the animal organism a like inequality of distribution is also observable. Thus, in the 
blood, it is found that phosphates and potash salts predominate in the corpuscles, and chlorides and soda salts in the plasma around. Again, as regards the distribution of potash and soda generally, it is noticeable that the former is the alkali belonging particularly to the formed tissue, the latter to the infiltrating fluids. Saline matter, therefore, is evidently concerned as one of the factors of the formative operations carried on, and no food can satisfy the requirements of life that does not contain an appropriate amount of certain saline principles.

In the egg, and also in milk, we have articles provided by nature for the special purpose of being employed in the construction and subsequent maintenance of the animal organism. Milk is complete in itself. In it exists, besides the organic principles, all the inorganic matter, including both salines and water, that is needed. The egg; taken as a whole, stands in a similar position, but it is not so with regard to the contents exclusive of the shell. It is well known that from the egg all the constituent parts of the young animal are formed-its skeleton as well as its various soft textures. Now, for the construction of the skeleton an amount of earthy matter is required which does not exist preformed in the soft contents of the egg, but has to be drawn from the shell. During the process of incubation, with the co-operation of the atmospheric air which permeates the shell, it appears that the phosphorus present in the yolk gradually undergoes oxidation and becomes converted into phosphoric acid. This acts upon and dissolves the carbonate of lime belonging to the shell, which thus as incubation proceeds becomes thinner and thinner. If the egg is to 
be compared with milk, both the contents and the shell must be reckoned to bring them into an analogous position.

It is necessary that saline matter receive due consideration as a nutritive element of food. It is perfectly true that in the preparation of food for human consumption the natural article is often considerably depreciated in nutritive value by the abstraction that may happen to have occurred. Meat soaked or boiled in water loses more or less of its soluable portion, and, included in this, are its nutritive salts. Roasted meat, on this account. is of higher value than boiled. In the process of salting a portion estimated at about fifteen percent of the nutritive juice escapes into the brine. In the boiling of vegetables nutritive principles, and particularly the nutritive of salts, are removed by the water. The separation that is effected in the dressing of flour leares this product in an inferior position to the grain from which it is derived. Both the saline and nitrogenous matters belonging to wheat are chiefly encountered in the outer or tegumentary part of the grain, and are, therefore, more or less excluded from white bread. It is a scientific fact, often proven by experiments, that a dog dies if fed on white bread, while its health does not suffer at all if its food consist of brown bread, or bread made of unbolted flour.

It must certainly be conceded that if our food consisted only of eggs, we should require, in order to satisfy the requirements of nutrition, to place ourselves in the same position as the developing chick, and consume the shell as well as its contents. Again, if corn formed our staple food, as it may happen to do in the case of the 
horse, etc., we should be obliged to consume the whole of the grain to obtain all of the nutritive principles we require. It is a mixture of animal and vegetable food, howerer, which forms our natural diet, and the diet which is actually employed by the great majority of mankind. Now, if we are supplied with the nutritive salts through meat or other articles consumed, we can spare them without detriment from our bread. Nor need there be waste involved in this proceeding. If our taste leads us to prefer bread made from white flour, and thereby to reject the outer part of the grain, it does not follow that in so doing we are committing an act of dietetic foolishness, for what we do not use ourselves may be, and in reality is, turned to account in feeding animals that are either kept to serve some useful purpose. or reared for consumption as food: and, in the latter case, the nutritive salts which we originally rejected in separating the bran from flour may actually reach us after all among the constituents of animal food.

\section{ANIMAL ALIMENTARY SUBSTANCES}

Animal food being identical in composition with the structures of the body, requires neither addition nor subtraction to enable it to administer to the purposes of nutrition. The chief characteristic of animal food is the large amount of nitrogenous matter it contains. This, it is true, adapts it for the construction and maintenance of the body, but food is also required for force-production, and provided a certain amount of nitrogenous matter be supplied, the force-production is better derived from one or other of the forms of non-nitrogenous mat- 
ter. Such may be effected by the presence of a certain quantity of fat, with the nitrogenous matter, and with a proper combination the adjustment may be made from animal food alone, so as just to meet the requirements without incurring waste on either side. Hence the advantage of the common practice, which is doubtless due to something more than accident, of eating some kinds of food rich in fatty matter, as bacon or pork, with food such as chicken, rabbit, etc., which consist mainly of nitrogenous matter.

Animal food is made up of:

1st. The various parts of animals.

2nd. Eggs; and

3rd. Milk with the products from it:-cream, butter and cheese.

The food falling under the first head is popularly classified into:

\author{
Meat, \\ Poultry, \\ Game, \\ Wild-fowl, \\ Fish.
}

The meats we ordinarily consume are all derived from vegetable feeders. They consist of:

$$
\begin{aligned}
& \text { Beef, } \\
& \text { Mutton, } \\
& \text { Veal, } \\
& \text { Lamb, } \\
& \text { Pork, } \\
& \text { Bacon, } \\
& \text { Venison, }
\end{aligned}
$$




\section{Rabbit, and Turtle for soups.}

The flesh, bones, internal or visceral organs, and even, as from the pig, the blood of the slaughtered animal, are all turned to account as food. They each require consideration. First, however, remarks will be made on the influence of age, sex, size, season, mode of life, nature of feeding, and mode of death, upon the flesh of animals.

The flesh of young animals is more tender than that of old, but experience shows that it is more resistant to the digestive powers. Veal and lamb, for instance, are found by the dyspeptic to tax the stomach more than beef and mutton. The flesh of an aged animal, as is well known, may be so tough as to render it almost refusable. The tissues of young animals are more gelatinous, less stimulating, and of less nutritive value than those of the adult and aged, which, instead, contain a larger amount of fibrin and of the flavoring principle. The flesh of very young animals, indeed, contains so very little fibrin, and flavoring principle, as to be almost umpleasantly soft, flabby, and insipid. Animals of middle age afford the most digestible and best flarored beef. Beef of the larger breeds of oxen is in greatest perfection at about seven years old; that of the smaller breeds, a year or two earlier. Cow beef can scarcely be too young. Vether mutton is best at four to five rears old: ewe mutton at about two years old.

Sex greatly influences the quality of the flesh, that of the female being more delicate and finely grained than that of the entire male, which, during the time that the genital organs are in a state of functional activity, 
may be so coarse and rank as to render it almost uneatable. The buck, bull, and ram form examples. Castration deprives the meat of this strong flavor, and improves it altogether for eclible purposes. Spaying also improves the edible qualities of the female animal. These operations, therefore, particularly that of castration, are commonly performed where the animals are destined to serve only as food. They are eren practiced in the case of the bird. The capon is an example; and it is well known that in this mutilated state the animal becones larger, fatter, and more tender than when the sexual organs remain intact.

In Scason and Out of Scason are common expressions as applied to animals. Their meaning is well known, and they signify that there is a season when animal is in a better state for consumption as food than at another. Neat is in general in lighest season during the first months of winter, that is, after the animal has been afforded the advantage of an abundance of fresh summer food; mutton and beef are never actually out of season, but they are in better condition and of better flavor during the months of November, December, and January, than at other times. Pork is absolutely out of season during the summer months. The season for young meats, as real and lamb, is when a sufficient time has elapsed after the breeding period for the animal to have arrived at a state suitable for consumption as food. The breeding period varies somewliat in different breeds, and thus a supply of young meat may be secured for some length of time. By exposure to certain conditions, also, the period of heat in a female may be considerably ad- 
ranced. In this way it is that lamb is procurable as an article for the table in the winter. With sheep kept in cold and poor pasture the lambing season is retarded.

The mode of life exerts its influence on the flesh of animals. In the wild state there is rery much less fat present than in a well-fed domesticated state. In the former case the meat also is higher in color and richer in flaror andi extractives.

Some kinds of food influence in a marked manner the cliaracter of the meat. Feeding oxen upon oil cake communicates a yellow color to the fat. Oily foods also have a tendency to make soft fat. Turnips give a rery noticeable flavor to mutton. The fragrant herbs belonging to different pastures produce their influence upon the taste of the meat. The art of feeding animals is directed to increasing the arrount of fat: they are fattened, in other words, for the table. If this fattening process be carried on only to a certain point, the alimentary value of the meat is increased, but when carried to an extreme, as we see it in some of the animals exhibited at the great cattle shows, the fat, as far as our requirements is concerned, is out of proportion to the nitrogenous matter, and thus an actual waste is incurred. Tn killing an animal the loss of blood certainly involves a loss or a waste of nutritive material. It would thereby be condemned if it did not possess counterbalancing adrantages. Besides rendering the meat more pleasant to the eye, it enables it to keep longer and improves the delicacy of its flaror. The Mosaic law is very strict regarding the killing of animals for food, and the regulations are such as to secure to the fullest extent the remoral of the blood. Jews, as a point 
of religion, wiil not eat the flesh of any animal that has not been killed by a slaughterer of their own persuasion. They consider their meat superior to that of others, and even some Christians prefer it. It is usual to keep an animal for a short time without food before being killed. and it is believed that the meat thereby keeps better. It is obvious. however, that the fasting must not be prolonged sufficiently to produce an unhealthy state.

To give additional whiteness to veal, which is looked upon as a clesirable quality for it to possess, it was formerly a custom to bleed the animal pretty freely a day or two before being killed. It is well known that meat is greatly improved in tenderness by being allowed to hang for some time after the animal is killed. While the fibres are set by the rigor of death, it is much harder than before or afterwards.

It must be understood that no fixed composition exists and that the analyses furnished by different authorities may show figures that somewhat differ. The relative amount of fat and nitrogenous matter, for instance, varies considerably in samples of meat obtained from different animals. Below is given analysis of cooked meat, which necessarily differs from that of fresh meat on account of the loss which occurs in cooking:

Composition of Cooked (Roast) MeAt, no Drippings BEING I.OST :

Boiled meat assumed to be about the same.

Nitrogenous matter. 27.6 .

Fat I 5.45

Saline matter

2.95

Water 54.00 
Beef is of a firmer texture and more satisfying to the stomach than mutton. Rightly or wrongly it is generally reputed as possessing also higher strengthening properties.

Composition of Lean Beef.

Nitrogenous matter 19.3

Fat 3.6

Saline matter $5 . \mathrm{I}$

Water 72.00

I 00.00

Composition of Fat Beef.

Nitrogenous matter. I 4.8

Fat 29.8

Saline matter $4 \cdot 4$

Water 51.00

100.00

Mutton appears to be more easy of digestion than beef. This is not, however, appreciable by a healthy person because the digestive power is in excess of what is required for the easy digestion of either when a proper anount only is consumed. In the dyspeptic, however, where a nice balance may exist between the digestive power possessed and that required-where, in other words, the digestive porver is only just sufficient for what is wanted, the usual experience is that mutton taxes the stomach less than beef. There are many, for instance, who find that while mutton can be eaten without exciting discomfort, beef rests somewhat heavily upon the stomach if it do not actually disagree. 
Composition of Lean Mutton.

Nitrogenous matter. I 8.3

Fat $4 \cdot 9$

Saline matter 4.8

Water. 72.00

I00.00

Composition of Fat Mutton.

Nitrogenous matter. I 2.4

Fat 3 I. I

Saline matter $3 \cdot 5$

IVàter 53.00

100.00

$V$ eal and Lamb. It has already been stated that these meats, although more tender, are more resistant to digestive action. They appear also to possess less strengthgiving properties. It need scarcely be said that there is a deeply rooted belief that for sustaining the powers under great exertion these meats are not to be compared to beef and mutton. They are meats that it is desirable to avoid, generally speaking, in cases of dyspepsia.

Composition of VEAL.

Nitrogenous matter I 6.5

Fat I 5.8

Saline matter

Water 63.00

100.00

Pork is of all meats the most difficult to digest. It is rich and trying to the stomach on account of the large 
quantity of fat it contains. All fat meats contain a relatively smaller proportion of water than lean on account of fat not being infiltrated with fluid to the same extent as the other tissues.

Composition OF Fat PORK.

Nitrogenous matter.

Fat

Saline matter

IVater
9.5 48.9

2.3

39.00

IOO.OO

Bacon. Cured meats generally are less digestible than the same meat in the fresh state. Bacon, however. ocenpies an exceptional position in this respect. Its fat, certainly, is less likely to disagree with the stomach than the fat of pork. It contains but a small proportion of water, and, therefore, weight for weight is an advantageous kind of food. It should not lose more than 10 to 1.) per cent in cooking.

\section{Composition of Dried Bacon.}

Nitrogenous matter. S.S

Fat $73 \cdot 3$

Saline matter 2.9

Water $\frac{15.00}{100.00}$

Composition OF GREen Bacon. Nitrogenous matter. 7.1

Fat 66.8

Saline matter 2. I Water $\frac{24.00}{100.00}$ 
Bone. The relative amount of bone in animals varies according to their condition. Taking the whole animal, 20 per cent may be allowed. In lean animals it is in too large a relative proportion viewed in reference to economy. In the various joints it is rarely less than 8 per cent, and in the shins and legs of beer it amounts to one-thircl or even more with reference to the total weight. The most economical parts are the round and thick flank, then the brisket, and, lastly the leg. In the case of mutton and pork, the leg is the most profitable, and then the shoulder. Pones contain some nutritive matter, broth nitrogenous and fatty. To extract it the bones should be broken up into small pieces and boiled for many hours. It requires seven pounds of bones to represent the equivalent of one pound of meat in nitrogen. Gelatin, which forms the basis of soup, is the nitrogenous principle extracted by boiling from bones.

Liver. The liver of many domestic animals is consumed as food. It is generally fried, and, thus prepared, forms a rich and savory dish. Its richness renders it an inappropriate food for a delicate stomach.

\section{Composition of Calf's Liver.}

Nitrogenous matter. 20. 10

Fat $5 \cdot 5^{8}$

Carbohydrate 0.45

Saline matter I. 54

Water 72.33

$$
\overline{100.00}
$$

Kidney. The substance of the kidney is of a close, fleshy nature. It can never be looked upon as otherwise than an article of difficult digestibility, but as regards this 
quality a great deal depends upon its mode of cooking. When lightly cooked it is soft, juicy, and agreeably sapid, but cooked for some time, and with the employment of a high temperature, it undergoes considerable contraction, and becomes hard, dry, comparatively tasteless, and exceedingly indigestible. The amount of fatty matter present is small.

Composition of Sheep’s Kidneys.

Nitrogenous matter

Fatty matter

Saline matter

Organic matter and loss

Water
I 7.250

2. 125

I. IOO

I. 325

78.200

Heart. The heart consists of fat and muscular tissue, like ordinary meat. The muscular tissue, however, is of a much closer texture and this gives the greater hardness which is well known to belong to it both in the cooked and uncooked state. On account of the closeness of texture and hardness, it forms an indigestible article of food.

Tripe. The tripe which is consumed as human food consists of the paunch or first portion of the ruminant stomach of the ox. This is the only instance of any part of the aimentary canal being applied to our own use, excepting in the case of the pig, where the chitterlings are cleansed and eaten. The muscular fibres belonging to tripe possess a different structure from those belonging to ordinary meat, and yield nore readily to digestion. Tripe, indeed, is an easily digestible article of food, but the fat present renders it somewhat rich. 
Composition OF Tripe.

Nitrogenous matter

Fat

Saline matter

Water.
I 3.2

16.4

2.4

68.00

100.00

Unwholesome Meat. Meat cannot be subjected, like many alimentary articles, to adulteration or falsification, but it may be in an unwholesome state, and thereby unfit for food. Good meat, according to the best of authorities, has the following characters:

1st. It is neither of a pale pink color nor of a deep purple, for the former is a sign of disease, and the latter indicates that the animal has not been slaughtered, but has died with the blood in it, or has suffered from acute fever.

and. It has a marbled appearance, from the ramifications of little reins of fat among the muscles.

3rd. It should be firm and elastic to the touch, and should scarcely moisten the fingers, bad meat being wet, and sodden, and flabby, with the fat looking like jelly. 4th. It should have little or no odor, and the odor should not be disagreeable, for diseased meat has a sickly smell, and sometimes a smell of physic. This is very discoverable when the meat is chopped up and drenched with warm water.

5th. It should not shrink or waste much in cooking.

6th. It should not run to water or become very wet on standing for a day or so, but should, on the contrary, be dry upon the surface. 
To this may be added that there should be no sign of the presence of parasites. The fat also should neither be deficient nor excessive.

There is one form of parasite which is frequently met with, particularly in the case of the pig, here giving rise to what is known as "measly pork." It consists of a little animal possessing a tape-worm-like head with a bladder-like tail, from which its name cysticcrus is derived. It lies in the flesh surrounded by a cyst, which in the pig is about the size of a hemp seed, and thus is easily seen. The cysticerci of beef and real are much smaller than those of pork, and require close inspection to discover them. When meat thus infested is eaten in the raw or imperfectly cooked state, it gires rise to the development of tapeworm in the alimentary canal. They can be killed by the meat being thoroughly well cooked throughout.

There are various diseases of an acute infections nature and malignant type, such, particularly, as rinderpest. anthrax, and pleuropneumonia, to which animals are subject. Can the meat of animals that have been thus affected be eaten without producing injurious consequences? The idea of it is repulsire, and, strangely, the answer to the question cannot be given in such a manner as our notions might lead us to expect. The conflicting opinions of various persons on this point show the amount of uncertainty that exists with regard to it.

It has been suggested that the prevalence of boils and carbuncles may be attributable to the unconscious consumption of meat from diseased animals, and plenty of statistics have been adduced in support of this view. 
Looking at the eviclence before us regarding the effects of consuming meat derived from animals suffering from infectious disease, the conclusion is that some kind of subtle poison exists, and that this may become neutralized or destroyed by the processes of cooking and digestion, but why such an erent should occur in some cases and not in others, is indeed difficult to understand. It is only right, however, to look upon all such meat as unsafe and unfit for human food. Tastes differ, as was shown by the Indian way of burying meat underground for months to putrefy, thus making for them a great delicacy. Fish. Fish is an important article of nourishment. A very large number of different kinds of it, both freshwater and salt-water, are consumed, giving great variety to this kind of food. The amount that must exist in the vast waters of the oceans may also be regarded as rendering the supply inexhaustible. In some places it constitutes the whole sustenance of the people. The inhabitants of the most northern parts of Europe, Asia, and America, where it is too cold for any of the higher forms of regetation to grow, are mainly dependent upon food of which the chief portion consists of fish derived from the sea. Although from time immemorial fish has formed an article of food, more or less consumed by most people, yet many prejudices used to exist with regard t. it. The Egyptian priests were forbidden to eat fish of any kind, under the idea that it increased the sexual appetite, or that it was the cause of leprosy. For the latter reason the people were also forbidclen to eat fish not covered with scales. In the writings of Moses it is stated: "Whatsoever hath fins and scales in the waters, 
in the seas, and the rivers, them shall ye eat-Whatsoever hath no fins or scales in the waters, that shall be an abomination unto ye." There does not appear to be any substantial foundation, however, for the belief that formerly prevailed, as the sturgeon-a fish without scales-is now extensively eaten.

The flesh of some fish is white, and that of others more or less red. The former is less stimulating and lighter to the stomach or more easy of digestion than the latter. The flesh of these fish contain but little fat, as the following analysis will show. The fat existing in the animal is especially accumulated in the liver, and in the cod-fish particularly, when in season, the liver is enormously gorged with oil.

Composition of White Fish.

Nitrogenous matter

Fat.

Saline matter

Water.
I 8 . I

I. $\mathrm{O}$

78.00

I 00.00

The flesh of salmon particularly presents a strong contrast in color to the white fish considered above. It approaches meat in redness, and is regarded as approaching it also more closely than other fish in sustaining properties. Fatty matter is incorporated with the muscular fibres, and there is also a layer of superficial fat beneath the skin. This is more abundant in the abdominal or thinner than in the dorsal or thicker part of the animal-hence the richer flavor, and thereby the prefeence given to the former for eating. 


\section{Composition of Salmon.}

Nitrogenous matter I6. I

Fat $5 \cdot 5$

Saline matter I. 4

Water. 77.00

100.00

The mackerel, eel, herring, sprat, are other fish characterized by the presence of fatty matter incorporated with the flesh. Thus it is that these fish are richer and less suited to a delicate stomach than the white fish. The eel especially is rich in fat, as is shown by the following analysis:

\section{Composition of Eels.}

Nitrogenous matter.

Fat

Saline matter

Water

\subsection{0}

Shell Fish. Shell fish are derived from both the crustacean and molluscous tribes of animals. They yield a less nutritive kind of food than that which has been already considered, but must nevertheless be looked upon as holding a position of considerable importance in an alimentary point of view. Shell fish, taken altogether, are more indigestible and apt to upset the stomach than other kinds of animal food. They frequentlý produce urgent symptoms of derangement. Sometimes the symptoms are those of gastro-intestinal irritation, as, for instance, nausea, vomiting, colic, cramps, and purging. 
Sometimes an eruptive disorder of the skin, and more particularly nettle-rash, is induced. So strong, indeed. is the tendency in some for such affection of the skin to be developed, that it is found necessary to scrupulously exclude shell fish from the diet.

The Crustaceans commonly eaten consist of the lobster, crab, crantish, shrimp, and prawn. They are all regardect as choice articles of food. The flesh belonging to them is white and firm.

Composition of the Edirle Portions of the Lobster.

Flesh Soft Intenal Spawn

\section{Nitrogenous matter}

Fatty matter

Mineral matter

Non-nitrogenous matter and loss,

Water
I9. I7O I2. I fO 2I.S92

I. $170 \quad 1.4+4 \quad \$ .234$

$1.823 \quad 1.7+9 \quad 1.99 S$

I.2I9 $0.35+\quad+.393$

76.6Is $8+31362.983$

$100.000100 .000 \quad 100.000$

The lobster occupies. a higher position in public estimation than the crab. The flesh of the two is much alike. but the flavor is different, that of the lobster being the more delicate, and apparently the least likely to disagree. The female or hen lobster. as it is called, is in special request for making sance, for the sake of the spawn or egss belonging to it. They are attached beneath the tail, and consist of little round bodies. They are black in their natural state, but become a bright red on boiling: They are pounded and mixed with the sauce. and thus give it after boiling the desired red color, as well as some amount of flavor. There is another part within the animal which becomes of a bright red on 
boiling. This is called the comal. It consists of the orary, and is generally used for garnishing. The flesh of the lobster is mainly found in the tail and claws. That of the claws is more tender, delicate, and digestible than that of the tail, which is firmer and closer.

Opsters. Oysters have always held a high rank amongst the lovers of good feeling. They are found on various parts of the coast, and are caltght by dredging, but instead of being consumed at once they are transferred to oyster beds in shallow waters for the purpose of being "fattened." Here they quickly undergo a marked increase in size, become more plump, and inprove in flavor. Oysters are a nutritious kind of food. Different opinions, however, prevail regarding their digestibility. Seeing, though, how often they can be borne without inconvenience by a delicate stomach; it may be concluded that they are not difficult to dispose of, and especially when it is considered that from the manner in which they are usually eaten, viz., without being masticated, they are rarely swallowed in as favorable state for digestion as other kinds of food. By many the whole animal is eaten, while those who are dainty orer them remove the outer fringed part or beard which constitutes the gills. Of the remainder there is a soft and a somewhat hard portion. The former consists mainly of liver, which in this animal is a very bulky organ. The latter is composed of the adductor muscle, which served to connect the two shells together. It forms by far the most indigestible part of the oyster, and should be carefully rejected where any weakness of stomach exists. Oysters are more digestible in the raw than in the cooked state. 
Cooking. Whether by grilling. scalloping. or stewing. coagulates ant hardens them, and thereby renders them more diticult of solution in the stomatr.

CompostTox OF Orsteks.

\begin{tabular}{|c|c|}
\hline Nitrogenous matter.......... & $1+.010$ \\
\hline Fatty matter............... & 1.515 \\
\hline 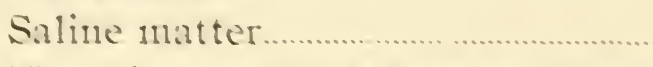 & 2.695 \\
\hline $\begin{array}{l}\text { Non-nitrogenons matter and loss. } \\
\text { Mater }\end{array}$ & $\begin{array}{l}1.395 \\
\text { S0.355 }\end{array}$ \\
\hline
\end{tabular}

100.000

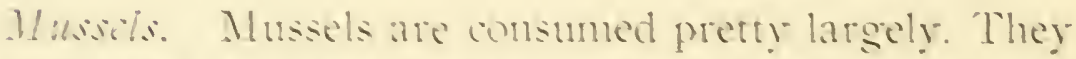
are subjected to a preparatory process of cooking. usmally hy stewing in their om licuor. There is a little tonguelike, hardish. dark-colored mass belonging o them, which is sencrally picked ont. moler the supposition that it is bad to tise as toud.

COMPOSITHON OH MLSELL.

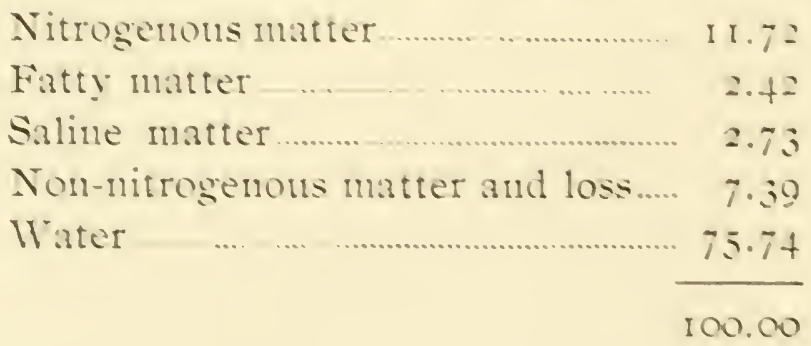

Elikis.

Egess necessurily eontain all that is required for the construction wi the boty. as the young amimal is developed from it. but, as pointed out heretotore, the shell must be taken inte aceount as well as its contents. During 
the process of incubation, in fact, the carthy matter of the shell becomes gradually dissolved and applied to the purposes of growth. Phosphoric acid, formed by the gradual oxidation of phospliorus, constitutes the solvent agent, and the shell is found to become progressively thinner and thinner, until at last it should be no thicker than a sheet of letter paper. Various eggs are eaten, including those of reptiles as, for instance, the turtle-as well as birds; but it is especially the egg of the fowl which is employed as a general article of food, and to this the succeeding remarks are intended to refer.

Composition of the Entrat Contents of the EgG.

Nitrogenous matter. 14.0

Fatty matter I0.5

Saline matter

Water 74.00

100.00

Composition of the White of EgG.

Nitrogenous matter 20.4

Fatty matter.

Saline matter I. 6

Water 78 oo $\mathrm{IOO} \mathrm{OO}$

Composition of the Yolk of Egg.

Nitrogenous matter I 6.0

Fatty matter. 30.7

Saline matter

Water 52.00 
The white of the egg, as shown by the above analysis, contains a considerably larger proportion of water than the yolk. It contains no fatty matter, but consists mainly of albumen in a dissolved state, and inclosed within very thin-walled cells. It is this arrangement which gives to the white of egg its ropy, gelatinous state. Thoroughly shaking or beating it up with water breaks the cells and removes the ropy state.

The yolk of the egg forms a kind of yellow emulsion. All fatty matter of the egg is accumulated in this portion of it, and it here amounts to as much as thirty (30) per cent. The fat is held in suspension or emulsified by the aluminous matter of the yolk, which constitutes a slight modification of that of the white, and is called vitellin. The yolk contains relatively a less proportion of nitrogenous matter than the white. The proportion of solicl matter, on account of the fat, is considerably greater. An enveloping membrane or bag surrounds the yolk, and keeps the fluid matter, of which it is composed, together. Being lighter than the white, it floats to that portion of the egg which is uppermost, but is kept in position between the two extremities by two processes of inspissated albumen, called chalazae, which pass and are attached-one to either end of the egg. The quality of eggs varies according to the food upon which the fowl is kept. Certain articles of food communicate a distinct flavor to the egg.

In an alimentary point of view, therefore, the white and yolk differ markedly from each other, the one being mainly a simple solution of albumen, the other a solution of a modified form of albumen associated with a consid- 
erable quantity of fat. Reckoning the weight of an egrg at two ounces, and that one-tenth of this consists of shell the contents will furnish the following amounts of dry constituents, the percentage composition given above being taken as the basis of calculation:

Dry Constituents of the Contents of an EgG.

Nitrogenous matter

Fatty matter

Saline matter
I I grains

82

I I

Total solid matter 203 “

Raw and lightly boiled eggs are easy of digestion. The hard boiled egg offers considerable resistance to gastric solution. and exerts a constipating action on the bowels. The egg changes by keeping, and certain devices are practiced to preserve its freshness. The shell. being porous, allows of the evaporation of fluid, and air accumulates in its place at one of the extremities. Thus, an egg under exposure to the air loses weight from day to day, and the diminution in density indicates the length of time it has been kept. For example, a solution of salt in the proportion of about ten per cent-that is, one ounce of salt in ten ounces of water,-will just allow a fresh egg to sink, while one which has been kept several days will swim. Bad eggs become sufficiently light to float even in pure water.

The air which finds its way through the pores of the shell into the egg causes gradual decomposition, uritil ultimately a state of putrescence is attained. With the view of excluding the air eggs are sometimes placed in lime water, and other heavy solutionis. The shell is also 
sometimes covered with a layer of lard, wax and oil or some other kind of fatty matter, and sometimes with a gum. By packing in bran, salt, or some such material. they keep longer than they otherwise would do, but it must be remembered that eggs easily acquire a taste from that which surrounds them. Immersed for some hours in a solution of salt, some of the saline matter penetrates and tends to preserve the egg under subsequent exposure to the air.

Fresh eggs are usually known by their translucency when held up to the light. By keeping they become cloudy, and when decidedly stale a distinct, dark, cloucllike appearance is discernable opposite some portion of the shell. Egg testers are cheap and usually made to fit an ordinary lamp chimney. Eggs are sometimes noticed to break spontaneously on being boiled. This occurs when the egg is suddenly immersed in a largish quantity of boiling water. The sudden expansion of the contents produced by the heat causes the shell to give way. Immersed in a small quantity of water only, the temperature is lowered sufficiently to prevent any immediate extensive, expansion, and then with the subsequent gradual elevation of the temperature, time is giren for a little fluid to be forced through the pores of the shell from the pressure within, and, perhaps, for the shell itself to undergo some expansion. A stale egg is less likely to become broken in this way than a fresh one, on account of the air which has replaced the eraporated fluid admitting easily of compression.

Egg Shells. In the Materia Medica of the Homeopathic school of medicine, the egg shell, known as ova 
testa, is triturated with sugar of milk and made into powders and tablets for the relief of certain disorciers of a functional nature.

The up-to-date doctor of medicine with a full and complete analysis of eg-yolk substances says thus:

Brain-matter; Eg-golk, and Seminal,fluid consist of :

Water,
Fats,
Protagon,
Cholesterin,
Nuclein,
Cerebrin,
Lecithin,
Minerals.

Also, says this up-to-date gentleman, egg-yellow contains an albuminoid called "vitellin," which is closely related to the albuminoid of blood (globulin); and contains also a ferruginous nuclein called "hematogen" (blood producing:) discovered by Professor Bunge, of Germany. Its other constituents are protagon, lecithin, fats, cholesterin, cerebrin, and phosphates, in which it is rich; also sulphates and traces of iron.

The chemical constitution of generative substance is also represented by albuminoids, lecithin, cerebrin, chloesterin, fats, phosphates and sulphates. And, besides, the relative proportions of the constituents of the foregoing substances are respectively very similar, only that the brain and egg yolk are richer in fats and the other in phosphorized proteids.

Therefore, eggs constitute the best and brainiest food for father and mother and child before and after conception and birth. 


\section{MILK.}

Milk, an article furnished and intended by nature as the sole food for the young of a certain class of animals, necessarily contains, like eggs, all the elements that are required for the growth and maintenance of the body. Holding the position it does, it may be justly regarded as the type of an alimentary substance.

Good milk is a homogeneous opaquely white or very faintly buff-tinted liquid, which is entirely free from any viscidity, and undergoes no change on being heated. It has a sweet taste, and a slightly perceptible agreeable odor. Its reaction is almost neutral instead of tending either towards acid or alkaline. when in a natural state and at the moment of remoral. A little later an acid character becomes perceptible, and is evidently due to the effect of change after removal. Its clensity varies, but. $10: 30$ may be looked upon as about the average in the case of cow's milk. Although appearing homogeneous to the naker eye, it in reality consists, as is shown by microscopic examination, of a clear liquid holding in suspension a multitude of little particles or globules, which constitute the cause of its opacity. These globules are of a fatty nature, and, being lighter than the surrounding liquid, gradually rise to the surface, and form the cream which collects at the top of milk that is allowed to repose. The ingredients of milk consist of :

Nitrogenous matter,

Fatty matter,

Lactin, or sugar of milk,

Mineral matter and

Water. 
The nitrogenous nuatter is chiefly composed of casein, a principle which, unlike albumen, is not coagulated by heat, but is coagulable by acicls, organic as well as mineral, and also by the nentral organic substance obtainable from the stomach, familiar to everyone as pepsin, which forms the active principle of rennet. It is casein which constitutes curd and the basis of cheese. It is thrown down, carrying with it in an entangled state the suspended iatty globules, not only by the addition of the agents mentioned, but as a result of the spontaneous change which milk undergoes upon exposure to the air. The cause of this spontaneous coagulation is the development of lactic acid by a fermentative transformation of the lactin. As is well known warmth greatly favors this change, and it does so to such an extent that during the hot weather of summer milk very quickly passes into a coagulated or curdled state. Contact with the smallest quantity of milk that has undergone the change also rapidly induces curdling throughout the whole bulk. Hence arises the necessity, as has been found by experience, of exercising the most scrupulous care in securing the utmost cleanliness of ressels used for the purpose of storage. It may further be mentioned that at the commencement of the change an amount of lactic acid may have been generated insufficient to curdle the milk at the ordinary temperature, but sufficient to do so at a greater heat, because the action of the acid is then more energetic. This accounts for the circumstance frequently noticed in the home, that milk may be liquid, and apparently fresh, at the ordinary temperature, and yet shall curdle upon being boiled. 
Besides casein, milk contains a little albumen, and a third nitrogeneous principle in small amount, which has been named lactoprotein.

The fatty matter constitutes butter. While existing in the milk it is suspended, as has been already mentioned, inder the form of microscopic globules. These globules appear to be surrounded by an envelope of casein or albuminoid matter, which becomes broken in the process of churning for the production of butter, so allowing the incorporation of the fatty matter to occur. It is seemingly on account of this envelope that ether fails to dissolve out the fat when simply shaken up with milk; for if a small quantity of an alkali, as for instance potash, which may be presumed to dissolve the envelopes, be previously added, then ether immediately takes up the fat, leaving a clear watery liquicl, consisting of the casein, etc., lactin, and salts.

Lactin forms one of the varieties of sugar, and remains dissolved in the liquid from which both the curd and butter may have been separated. It has a less sweet taste, and is less soluable in water than ordinary sugar, is nearly insoluable in alcohol and ether, readily crystallizes, and reduces the cupro-potassic solution like grape sugar, but is not directly susceptible of alcoholic fermentation. Alone it forms a staple compound, but in contact with decomposing nitrogenous matter it undergoes conversion into lactic acid, which accounts for the sourness that milk acquires on keeping.

The mineral matter and zuater comprise the inorganic principles required for the purposes of life. 
According to competent analyses, colv's milk contains 14 per cent of solid matter, which is distributed as follows :

\section{Composition of Coiv's Milik.}

Nitrogenous matter 4. I

Fatty matter.

Lactin

Saline matter

0.8

Water 86.00

I 00.00

One pint of milk of the above composition, reckoned at a sp. gr. of 1030 , which will give 9012 grains as its weight, will contain the following amounts of the several solid constituents, represented in grains and ounces:

Solid Constituents in One Pint of Milk.

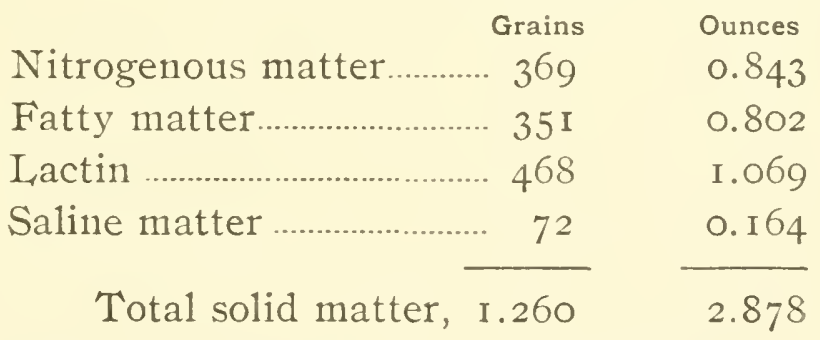

The milk of the cow most closely approximates to that of woman, but it is rather more highly charged with each kind of solid constituent. Next follows the milk of the goat, which, taken altogether, is again rather richer. That of the sheep is characterized by its marked richness in nitrogenous matter and butter. The milk of the ass and mare presents a striking difference from the rest. The peculiarity consists of the small amounts of nitrogenous matter and butter, and the large amount 
of lactin or sugar. The milk of the mare forms the higher representative of this peculiarity of the two, and so large is the amount of sugar contained in it that in Tartary it is fermented and converted into a spirituous liquor which is known by the name of koumiss. Asses' milk is well known to form a most useful aliment for persons too delicate in health to bear cow's milk. Its prominent characters as an article of food are siveetness of taste and facility of digestion. It is said, however, to have the objection of being sometimes apt to occasion diarrhoea.

With reference to the casein, it is stated that the coagulum or curd of woman's milk is "in general somewhat gelatinous, and not so dense or solid as that of cow's mik, and, therefore, more easily digested by the child's stomach."

Evidence is not wanting to show, as might be anticipated, that the quality of the milk is influenced by the nature of the food. It has been clearly ascertained that an insufficient diet quickly leads to an impoverishment in solid material. It is nothing more than might be expected that to maintain the milk in good condition, a proper and sufficient diet must be supplied; and in the case of the cow, no food is considered equal to that which is yielded by the fresh pasture of country fields. the plants of which give a richness, sweetness, and agreeable aroma, which cannot be supplied by any other mode of feeding.

There are certain products and modifications of milk, as cream, skimmed milk, buttermilk, curds, whey, butter and cheese, which now require consideration. 
Crean. Crean consists mainly of the fatty matter of milk, which, by virtue of its lightness, rises to the surface, the milk being allowed to repose for some time for the purpose. It contains some of the watery liquid part of the milk which holds in solution the other constituents. The composition of cream will necessarily vary a great deal according to its purity.

\section{Composition of Cream.}

Nitrogenous matter.

Fatty matter. 26.7

Lactin 2.8

Saline matter

I.S

Water 66.00

100.00

Skimmed Milk is the residue of milk from which cream has been collected. It is simply milk deprived of a certain amount of its fatty constituent. Being less rich than ordinary milk, it sometimes forms a useful aliment for a weak stomach.

Composition of Skimmed Milk.

Nitrogenous matter. 4.0

Fatty matter

I. 8

Lactin

$5 \cdot 4$

Saline matter

0.8

Water. 88.00

I00.00

Buttermilk. When butter is prepared directly from milk a thin residuary liquid is yielded, which is known by the name of buttermilk. It contains a less amount of 
fatty matter than skimmed milk. Mixed with other food it is by no means an insignificant article of nourishment, containing as it does, the nitrogenous matter, sugar, saline matter, and a small portion of the fatty matter of the milk.

Composition of Buttermilk.

Nitrogenous matter

$4 \cdot \mathrm{I}$

Fatty matter

0.7

Lactin

6.4

Saline matter

o. 8

Water 88.00

100.00

Curd. The essential basis of curd is casein; but, as this principle undergoes coagulation during the transformation of milk into curds and whey, it entangles and carries with it the suspended milk globules. Curd, therefore, consists of the nitrogenous portion of milk mixed with the chief part of its fatty element. It constitutes the basis of cheese.

Whey. This forms the opalescent liquid left from the separation of the curd; it contains the lactin and salts of the milk, and likewise retains a little casein and fatty matter. It is of some value but not much, in an alimentary point of view.

\section{BUTTER.}

Butter is the fatty portion of milk, and is obtained by the process of churning, either cream or the milk itself being subjected to the operation. The effect of churning is to cause the milk globules to run together or 
coalesce, and thus to become incorporated into a solicl mass. This is supposed to be brought about by the mechanical rupture, in the first place, of the envelopes of the globules, the contents of which are then permitted to become agglomerated: and, it is found by experience that the process is facilitated by being conducted at a temperature of aloont sixty degrees Fahrenheit. When the butter is formed it is removed from the churn and well kneaded and washed with water, to remove as much as possible of adhering casein and other ingredients of the milk, and the more completely this is effected the better will the butter afterwards keep. More or less salt is added to promote still further its power of keeping, and to suit the different tastes of its consumers.

The pure fatty matter of butter is composed of a mixture of several fatty principles. Six of them are enumerated below:

\section{Margarin, \\ Olein, \\ Caprylin, \\ Butyrin, \\ Caprin, \\ Caproin.}

These are neutral fats, and are resolvable into glycerin and margaric, oleic, caprylic, butyric, capric, and caproic acids respectively: the first two acids being of a fixed, and the last four of a volatile nature. It is to the latter agents that the characteristic taste and smell of butter are due, although they are present only in small amount.

Fresh butter, especially in hot weather, is very prone to undergo change, and in the course of a short time to 
become rancid. This arises from the nitrogenous matter of the milk with which the butter is impregnated acting as a ferment, and leading to the liberation of the fatty acids. The more completely butter is deprived of this adrentitious matter by mashing. the better is it found afterwarls to keep. Butter is a form of fatty matter less likely than most others to disagree with the stomach. This applies to butter in a perfectly fresh or unclianged state: when rancid it is rery likely to occasion gastric derangennent.

Cherse consists of the casein of milk with a varying admixture of butter, according to the manner in which it has been prepared. The casein is coagulated usually by the employment of rennet. but sometimes by the agency of an acid. In being precipitated the casein entangles and carries with it the suspended fat-globules (butter) of the mills. After coagulation has been effected the curd is collected and subjected to pressure in moulds. to deprive it. as far as possible, of the liquid portion of the mill: or whey. Fatty matter gives softness and richness to cheese. but, at the same time, renders it more prone to change and decay on keeping. It is the poor and close cheese. such as is made from skimmed milk, which is found to keep the best.

Composition of Chense.

Nitrogenous matter $33 \cdot 5$

Fatty matter $24 \cdot 3$

Saline matter $5 \cdot 4$

Water 36. So 
Composition of Skim Cheese.

Nitrogenous matter. 44.8

Fatty matter 6.3

Saline matter 4.9

Water 44.00

100.00

On account of its richness in nitrogenous matter cheese constitutes an article of considerable dietetic value. Amongst the poorer inluabitants of rural districts it enters as an important aliment into the daily diet, serving to sipply the nitrogen which is deficient in the bread or other kind of vegetable food which is employed as the staple article of subsistence.

\section{Vegetable Alimentary Substances.}

Although vegetable substances differ so much physicially, and in some respects, also, chemically, from the components of animal beings, they are susceptible of conversion into those components, and, alone, contain all that is absolutely requisite for the support of animal life. A more complex elaborating system, however, is required to fit them for appropriation than is the case with animal substances, and accordingly it is found that the digestive organs of the herbivora are dereloped upon a larger and higher scale than these of the carnivora.

The regetable products that form even common articles of food are exceedingly varied and numerous. To attempt to arrange them under any strict classification would only lead to embarrassment, and often involve practical inconvenience. It will be sufficient for the pur- 
poses of description to distribute them into the following general groups:

Farinaceous seerts,

Oleaginous seeds,

Tubers and roots,

Herbaceous articles,

Saccharine and

Farinaceous preparations.

Farinaceous Seeds.

These rank first in importance amongst vegetable alimentary products. They are alike plentifully yielded, of easy digestion, and of high nutritive value. It is not surprising, therefore, to find that the farinaceous seeds form the largest and most widely consumed portion of our regetable food. Of the farinaceous seeds, those as wheat, oats, barley, rye, rice, corn, etc., derived from the cerealia - a tribe of grasses, take the first place as articles of food: and next follow those derived from the leguminosoe, or pulse tribe, as, for instance, peas. beans, and lentils. Some other farinaceous seeds will be mentioned as employed, but they are of far less significance in an alimentary point of view.

\section{The Cerealia.}

The rarious cereal grains agree in their general composition, but differences exist in the relative amounts of the constituent principles, which give them different degrees of alimentary ralue.

The principles enumerated are:

1st. Nitrogenous compounds, consisting of gluten, albumen, casein, and fibrin, with an active principle, chiefly encountered in the cortical part of the grain, 
which, like diastase, possesses the power of converting starch into sugar. The material known as gluten, as will be more particularly mentioned further on, comprises a mixture of gluten, casein, and fibrin.

2nd. Non-nitrogenous substances, as starch, dextrin, sugar, and cellulose.

3rd. Fatty matter, including a volatile oil, which constitutes the source of the odorous quality possessed by the grain.

4th. Mineral substances, comprising phosphates of lime and magnesia, salts of potash and soda, and silica.

Oats are rich in nitrogenous matter, fat, and salts. Corn contains a fair amount of nitrogenous matter, but is poor in salts. Corn further stands out from all the rest by virtue of the large amount of fatty matter present. Barley occupies a mean position with reference to all the constituents. Rice is characterized by richness in starch, and poorness in nitrogenous matter, fatty matter and salts. The knowledge thus supplied is of considerable value in relation to the employment of the several kinds of grain as articles of food.

\section{WHEAT.}

Wheat may be said to form the most useful article of the vegetable foods, and hence it is one of the most ex. tensively and widely cultivated of the cereal grains. As supplied for use, wheat consists of the grain deprived of the husk with which it was originally invested. Each grain is composed of a hard, colored, tegumentary portion, and a central, easily pulverizable, white substance, which yields the product constituting flour. 
The tegumentary portion consists, externally, of an exceedingly hard layer, which is of a dense, ligneous nature, and so coherent that it presents itself mnder the form of scales when wheat is subjected to the ordinary process of grinding. This constitutes the greater bulk of bran. The central white portion of the grain is chiefly composed of starch; but nitrogenous, fatty, and saline matters are all present also, to some extent. The nitrogenous matter consists of sereral principles. There is albumen, mucin or casein, fibrin, and glutin. What is called gluten-the ductile, tenacious, raw material left when flow is kneaded with water, and afterwards washed to remove the starch-does not represent a simple or pure nitrogenous principle. The albumen of the flour is not present in it. This latter principle, being soluble in water, is carried away with the starch in the process of washing. It luas often been said that the external part of the grain is richer than the central in nitrogenous matter. This remark, howerer, is not to be taken as applying to gluten. Gluten, indeed, preponderates in the central farinaceous part, the nitrogenous matter of the exterior being principally composed of regetable fibrin. It is to glutenand this exists to a special extent in wheat-that wheaten flour owes its aptitude for being made into bread. This substance, by virtue of its tenacity, and its susceptibility of solidification by heat, is capable of entangling gas generated or incorporated amongst it, and then becoming fixed in such a manner as to furnish a light, spongy, or porous article, like well-made bread.

Medium wheat usually yields from $9: 2$ to $S 0$ per cent of good flour, and from so to 10 per cent of bran. Below are two analyses of flow which differ a trifle: 
Composition of Flour.

\begin{tabular}{|c|c|}
\hline Nitrogenous matter .......... & I0.8 \\
\hline 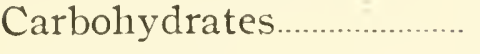 & 70.5 \\
\hline Fatty matter & 2.0 \\
\hline Mineral matter & I. 7 \\
\hline 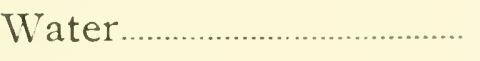 & 15.00 \\
\hline
\end{tabular}

The anount of gluten in wheaten flour ranges from $S$ to 15 per cent, the average being about 11 per cent.

Bread. Of all the articles of regetable food, bread must be considered as the most important to us. It constitutes a product of art, and amongst all cirilized people the process of manufacture is known and put into practice, evidently on account of the farorable state in whicl, the elements of food are placed for undergoing digestion. It is only from some kinds of grain that bread can be made, and no bread is egual to that prepared from wheaten flour. The amount of gluten present, for which? this kind of grain is distinguished, gives it the property for yielding a light and spongy form of bread, and it is to this lightness or sponginess that bread owes its easy digestibility: for, according to its porosity, so is the facility with which it is penetrated and acted upon by the secretion of the stomach. The first requisite torrat dis the manufacture of bread is that the grain should be resluced to a pulverized condition. By the ordinary process it is ground in a whole state and conrerted into meal. This may be used for making bread-as is the case in what we call "brown bread"-but, as a rule, the Hour is separated, and this only employed. 
Bread is a firm and porous substance, which is easy of mastication and which, while preserving a certain amount of moisture, is not wet or clammy. To convert flour or meal into a substance of this kind constitutes the art of bread-making. A paste or dough is made by manipulation, either by kneading with the hands or by machinery, with the requisite quantity of water. Porosity is given by intimate incorporation with carbonic acid gas-either generated within, as by fermentation, or the use of one or other form of "baking powder;" or may be supplied from without by another process. The gluten present. by virtue of its tenacity, holds the vesicles of gas and allows a spongy mass to be formed. While in this state, solidification is effected by the aid of heat applied in the process of baking, and thus is formed a permanently vesiculated or porous article. Such in a few words constitutes the rationale of the process of bread-malking.

The usual practice in making bread by fermentation is to mix a certain quantity of the flowr with the ferment. some salt, and lukewarm water. These are kneacierl into a stiff paste or dough, which is placed aside in a warm situation for some hours usually. The mass gradually swells up. from the evolution of carbonic acid gas, or. as it is generally termed "the sponge rises." When the sponge is in active fermentation it is thoroughly kneaded with the remainder of the flour, salt, and water. and again set aside for a time in a warn situation. Fermentation extends throughout the whole, and at the proper moment the dough is made into loaves and introduced into the oren. Herein constitutes one of the chief points in the baker's art. Cnless fermentation has been ailowed 
to proceed far enough, a heary loaf is the result; and if allowed to proceed too far, an objectionable quality of bread is the result, caused by the commencement of further fermentation. Time also must not be allowed for the loaves to sink before being baked. Under the influence of the heat of the oven an expansion of the entangled resicles of gas ensues, and occasions a consiclerable further rising of the dough; and, with the subsequent setting of the substance of the loaf a permanently vesictulated mass is formed.

In average practice, 100 pounds of flour will make about 140 pounds of bread. The art of the baker, however, is to increase this quantity, and he does it by hardening the gluten through the agency of a little alum, or by means of a gummy mixture of boiled rice, three or four pounds of which, when boiled for two or three hours in as many gallons of water, make a sack of flour yield far more than it otherwise should. An evaporation of water occurs, and causes bread to lose weight on keeping. The loss proceeds most actively while hot from the oven.

Composition of Bread.

\begin{tabular}{|c|c|}
\hline Nitrogenous matte & 8.1 \\
\hline Carbohydrates ........ & 51.0 \\
\hline Fat matter & I. 6 \\
\hline Mineral matter........ & $2 \cdot 3$ \\
\hline 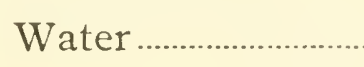 & 37.00 \\
\hline
\end{tabular}

Biscuits. Biscuits are a useful wheaten product, on account of their property of keeping, which is owing to 
their being dried as well as baked. Some biscuits are made from flour and water only, or flour, water, and a very little butter to diminish the hard and flinty character which they otherwise possess. Other biscuits are made with the addition of milk, and some with the addition of sugar also; and lightness may be given either by a baking powder or the carbonate of ammonia, which, being a volatile salt, is dissipated with the heat of the oven, and in escaping raises the dough. There are also various fancy biscuits, each kind containing, in addition to the ordinary ingredients, some special article. Plain biscuits constitute an easily digestible form of food. Stale biscuits, on being moistened and rebaked, are restored, as is stale bread, to nearly the condition of new.

Composition of Biscuits.

Nitrogenous matter.

Carbohydrates

Fatty matter

Mineral matter

Water
I 5.6

$73 \cdot 4$

I.3

I.7

8.00

I 00.00

\section{OATS.}

The common oat is derived from the avena sativa. A considerable number of varieties of the plant are cultivated, yielding oats, which may be arranged under the two heads of white oats, and red, dum, or black oats. As met with in commerce, oats consist of the seeds inclosed in their husks. The husk amounts to nearly thirty (30) per cent, the remainder comprises the kernel of the seed. Oatmeal constitutes the product of grinding 
the kiln-dried seeds, deprived of their husk, or outer skin. It is not so white as wheaten flour, and its taste is peculiar.

Composition OF OATMEAL.

Nitrogenous matter. I 2.6

Carbohydrates 63.8

Fatty matter 5.6

Saline matter 3.0

Water I 5.00

100.00

Composition of Dried OAts.

Nitrogenous matter I $4 \cdot 39$

Starch 60.59

Dextrin, etc. 9.25

Fatty matter $5 \cdot 50$

Cellulose 7.06

Mineral matter

3.25

\section{00.00}

The nitrogenous matter of the oat is formed chiefly of a principle allied to casein, called avenin. On account of the absence of g-luten, oatmeal cannot be resiculated and made into bread, like wheaten flour. It is devoid of the tenacity of adhesiveness which is requisite to hold the resicles of gas and give porosity or lightness to the mass. It is, howerer. made into thin cakes, by mixing into a paste with water, and then baking on an iron plate.

Oats form an important and valuable article of food. With a proportion of nitrogenous matter which bears a farorable comparison with that of wheat, they stand next to corn amongst the cultirated cereals in the amount of 
fatty matter present. The percentage of saline matter is also high.

\section{BARLEY.}

Barley is obtained from several species of hordeum, the favorite being hordeum distichon, or common summer barley, of which several varieties are cultivated. It is met with in commerce as a grain, inclosed in the husk. The product, when whole grain is ground, forms barley meal.

Composition of Barley Meal.

Nitrogenous matter ............................. 6.3

Carbohydrates ………………......... 74.3

Fatty matter ……………………...... 2.4

Saline matter ………………….......... 2.0

Water.

15.00

I 00.00

The nitrogenous matter of barley exists under the form of albumen and casein. There is little or no gluten, and hence, like oatmeal, it cannot be made into a vesiculated bread. Barley bread is, therefore, usually made by nixing wheaten flour with the meal.

Malt is the product yielded when barley has been allowed to germinate, and the germination has been stopped at a certain point by subjecting the grain to heat on a kiln. As a result of the process, a peculiar active nitrogenous principle, called diastase, is dereloped, which has the power of effecting the conversion of starch into dextrin and sugar; and through this, malt differs from barley in a portion of the starch being represented by sugar. Malt infused in hot water yields Sweet-wort, 
which is rich in saccharine matter. This is used for making Beer. Malt is also used to some extent as a food for cattle.

\section{RYE.}

The common rye, or secale cercalc, is extensively cultivated. It is of a hardy nature, and is ustually sown in ground where the soil is too poor for wheat to grow. The lightest of sandy soils will produce fair returns in rye and rye straw, eren though not fertilized.

In external appearance the rye grain presents a closer resemblance to wheat than any of the other cereals. It is, however, darker in color and smaller in size. In the center the grain is white and farinaceous, but towards the exterior it is brownish. As met with in commerce, it is cleprived of the husk, as in the case of wheat. It is ground and used under the form of rye-meal.

Conposition of Rye Meal.

Nitrogenous matter

S.O

Carbohydrates 73.2

Fatty matter.

2.0

Saline matter

I. 8

Water I 5.00

I 00.00

Composition of Dried Rye.

Nitrogenous matter

Starch

I 2.50

Dextrin, etc. 64.65

Fatty matter 14.90

Cellulose

2.25

Mineral matter.

2.60 
The nitrogenous matter of the reve consists of fibrin. sluten. and alhumen. From the nature of its nitrogenoms matier. rye approaches nearer to wheat than the other cereal grains in the aptitude ot its Hom for making a resiculated bread. Rye bread is considerable of a staple foul in Belgimm. Holland. Prussia. Gemmany and Russia. Rye bread tills but litte short of wheaten bread in nutritive value. Its color and acid taste. howerer. render it not to the liking of those who are macomstomed to it. It has at times a laxatire action. Rye is nsed for malting and by distillers.

The cereals are subject to become the seat of stomth of parasitic tungus. Which gives to the grain deleterious properties: and. of all of them. rye is the most prone to he attacked in this way. The affected srain molerges derelopment. so as to project considerably beyond the husk, and it may attain mpmards of fom times its size in the orlinary state. On accome of this excessive growth. it can be separated by sifting from the maffected seed. and. muless this is done to an eregotized crop. serions eomsequences may arise from its consmulptivil as toud. At varions times. indeed. the imbahitants of clifferent parts ot the Old Morld hare heen striclien with fatal illness from this camse. Two classes of sympwoms are produced. demominated the iomilwsi:i and gangronoms forms of argotism. In the one. the phenomena consists of neariness. gicldiness. contraction of the muscles of the extrometies. formication. Aimness ot sight. loss ot sonsibility. roracious appetite. rellow comtenance. and comvenlsions. followed hy death: in the other. there is also formication, that is. a fecling as if insects were 
creeping over the skin, and voracions appetite, and with this there occur coldness and insensibility of the extremitics, followed by gangrene. I fluid extract of ergot is cxtensirely used by physicians.

\section{CORN.}

The common maize, or corn, is a native of tropical America, and is now extensively cultivated in many other countries the world over. The grains of corn are variously colored, but those most commonly met with are vellow. The ears when nearly full-grown are a farorite delicacy. when they are boiled and the grain eaten with salt and butter.

A small variety of corn. with translucent and deeply colored grains is known as pop corn. This possesses the property, when gently roasted, of bursting, turning inside ont, and swelling to many times the original size, in which condition it is eaten with a little salt, or clipped in a sweet solution.

Maize or corn meal is not adapted for making bread, on account of its deficiency in gluten, without the admixture of wheaten or rye flour. The common brown bread of New England is made from a mixture of rye and corn meal. Used alone, corn meal, like oatmeal and barley meal, is made into a cake, and this when roasted or fried has a variety of names, johnny-cake, hoe-cake, pone, or Indian lread.

Composition of Cord Ment.

Nitrogenous matter. I I . I

Carbohydrates 65 . I 
A TREATISE ON FOODS.

Fatty matter S. I

Saline matter I. 7

Water 14.00

100.00

Composition of Dried Corn.

Nitrogenous matter

Starch

I 2.50

Dextrin, etc. $67 \cdot 55$

Fatty matter. 4.00

Cellulose S.So

Mineral matter

5.90

I. 25

100.00

While containing an arerage annount of nitrogenous matter, corn is characterized and distinguished, as is shown by the abore analyses, from the other cerealia by the large amount of fatty matter present. Is regards this quality, none of the other cerealia exhibit a close approach to it. On account of the fatty matter present, corn acquires, on keeping for some time, an unpleasant rancid taste, from the ustral change induced by exposure to the air. Containing as it does, about the same percentage of nitrogenous matter as soft wheat, and upwards of four times the amount of fatty matter, corn stands in a high position as regards alimentary ralue. It is largely used both for feeding and fattening animals.

Corn is destined to be fed even more, to the exclusion of oats. The Ohio Experiment Station has for some time been conducting experiments which tend to show that corn is a cheaper food for working horses than oats. It has long been the opinion of most all horsemen that 
oats were the best of all grains for feeling horses. Experiments have proved that this is a mistake and that farm horses may be fed on corn with safety and economy, and with the assurance that they are well nourished, strong and serviceable with this food judiciously used. It is shown that a large portion of the bulk of oats (see composition of oats), is the covering of the oats which is hard to digest, and is of no more food value than wheat straw. In buying oats we have to pay for this waste hull covering at the same price per pound as we pay for the kernel. while in buying whole corn we have no such waste hull of covering. The value, as a food, of corn, has not yet been sufficiently recognized by the world. The use of corn for the family is being extended now everywhere. Corn meal made into puddings, cakes, etc., is remarkably nourishing and desirable in every way. For poultry it is the farmer's standard food, though he overdoes it usually by not providing enough of a variety with the corn, for it cannot be denied that any animal thrives best with an occasional change in food. In France they have discovererl that corn may replace oats in feeding horses, and with good results. The composition of oats and corn is very similar. With poultry it is claimed that all experiments have proved whole corn to be just as good as cracked or ground corn for feeding.

\section{RICE.}

The common rice, or orywa sativa, is extensively cultivated in warm countries. It supplies the principal food of about a third of the human race. There is a large number of varieties of the plant cultivated, and con- 
siderably more than one lnundred different kinds are grown in India. Rice is consumed as food. both in the state of grain and ground into flonr.

Composition of Rice.

Nitrogenous matter

6.3

Carbohydrates

79.5

Fatty matter

0.7

Saline matter

0.5

Water.

1300

100.00

Conposition of Dried Rice.

Nitrogenons matter.

Starch 7.55

Dextrin, etc. SS. 65

Fatty matter

I. 00

Cellulose

O. So

Mineral matter

I. IO

$\frac{0.90}{100.00}$

Rice is characterized by the large proportion of starch, and the small proportions of nitrogenons, fatty, and mineral matter, it contains. In composition it must be looked upon as presenting considerable analogy to the potato. Rice, like the potato, is largely used for the manufacture of starch.

Rice is too poor in nitrogenous matter. fatty matter, and salts, to yield alone what is wanted in an aliment, unless consumed in very large quantity, thereby sacrificing a considerable portion of its starch. The starch, in other words, is out of proportion to the other alimentary principles, looked at in relation to the requirements of the system. Associated with other articles to compensate for the deficiency in the principles named, 
rice constitutes an exceedingly valuable food. It lias the adrantage of possessing an easily digestible starch granule, and so is found a useful aliment in disordered states of the alimentary canal. In the case of persons suffering from diarrhoea or clysentery it agrees better than any other kind of solicl food. It certainly exerts no laxative action, as many of the cereals do, and is often regarded, indeed, as having an opposite effect, but it probably occupies a neutral position in this respect. Rice is best cooked by thoronglily steaming. If boiled in water it loses a portion of the already small quantity of nitrogenous and saline matter it contains. It does not admit of heing made into bread, but is used mixed with wheaten flowr to make rery white bread.

\section{MIT,T,ET.}

The common millet, panicum milacemm, is a native of the East Indies, but is cultivated in many parts of the world. There is a very large number of varieties of millet. the srain of which is mostly used as food for poultry and other domestic animals. In nutritive value it ranks about equal to rice.

\section{BLCKIVHEXT.}

Buckwheat, although not a cereal, may be conveniently referred to in connection with the cereal grains. The common buckwheat is a native of Central Asia, and is said to have been introduced into Europe by the Crusaders. The name buckwheat is a corruption of the German buchaciscu (beechwheat), drawn from its resemblance to the seed of the beech tree. The plant grows very quickly and yields abundantly, but, as it is destroyed 
by frost, it camnot be sorm until the season for cold weather has passed. No grain is eaten so eagerly by poultry. and it is sometimes given to horses instead of oats, or in combination with them. The seed is covered with a hard rind, or thin shell. which has to be removed before it is fit for being eaten by cattle. Then used for human food it is usually made into thin cakes. which are very good eating.

Composition of Beckinheat.

\begin{tabular}{lr} 
Nitrogenous matter & I3.10 \\
Starch, etc. & \\
Fatty matter & 300 \\
Cellulose & 3.50 \\
Mineral matter & 2.50 \\
Trater & 13.00 \\
\hline & \\
\hline & 100.00
\end{tabular}

\section{LEGUMINOU'S SEEDS.}

This group of farinaceous seeds, which includes beans. peas, and lentils, is characterized by the large proportion of nitrogenous matter they contain. In this respect they stand strikingly in advance of the cerealia, for the amount may be twice as much as that contained in an ordinary kind of wheat. The form under which the nitrogenous matter is present is chiehy as a substance called legumin. which is a representative of regetable casein.

By rirtue of their composition, the leguminous seeds possess a high nutritive value, and furnish a food which is more satisfying than regetable food generally to the stomach, and more closely allied in a dietetic point of view to the alimentary products supplied by the animal 
kingdom. They thereby furnish an advantageous substitute for animal food for those who fast during lent and on other days, and it is probably on this account that such foods are largely consumed in France and other Catholic countries. Their large amount of nitrogenous matter adlapts them for consumption in association with articles in which starch or fat is a predominating principle. With rice, therefore, they form an appropriate combination, this admixture being a staple food in many places. As a drawback to their high nutritive value, the leguminous seeds must be ranked as difficult of digestion. They require prolonged boiling to render them tender and digestible. They are apt, besides lying heavy on the stomach, to occasion flatulence and colic, and the flatus is charged with a considerable quantity of sulphuretted hydrogen, arising from the sulphur which the legumin contains. They are also regarded as stimulating or heating to the system, and it is on account of this property that a moderate quantity of beans proves a serviceable adjunct to the food during the winter montlis.

\section{BEANS.}

Beans are derived from the faba vulgaris, a plant which is supposed to be a native of the East, but which has been cultirated in England from time inmemorial. There are sereral varieties, one of which is the common field bean, and another the broad bean of the garden. The latter is boiled in the young and fresh state, for use at the table as a regetable.

Composition of Beans.

Nitrogenous matter.

Starch, etc. 
Cellulose 3.0

Fatty matter

Saline matter

100.00

\section{PEAS.}

There are several varieties of peas. Some, derived from pisum arvense, are known as field peas. Others, forming the garden pea, are derived from the pisum satioum, a native of the South of Europe. Peas are grown for the ripened and dried seeds, and also for eating as a succulent vegetable. In the latter case the pods are gathered before they have arrived at maturity, and the seeds separated and consumed in a green state.

Peas, when quite young, are tender and sweet, and far more digestible, but less nourishing; than peas in the mature state. The latter, like other leguminous seeds, require slow and prolonged cooking to render them soft and digestible.

\section{Composition of Dried Peas.}

Nitrogenous matter

Starch, etc.

Cellulose

Fatty matter

Mineral matter

Water

\section{8} 58.7

$3 \cdot 5$

2. I

2. I

8.30

IOO.00

\section{LENTILS.}

Lentils form another product yielded by the leguminous tribe, and one of great antiquity. They are eaten quite extensively in some parts of Europe and the Far 
East. They are derived from the crumm lens, which constitutes a kind of tare.

Composition of Lentils.

Nitrogenous matter

Starch, etc.

25.2

Cellulose $5^{6.0}$

Fatty matter

Mineral matter

2.6

Water

100.00

\section{OLEAGINOUS SEEDS.}

There are various seeds, denominated nuts, which are devoid of starch, but rich in oily matter. The starch of the cerealia appears to be replaced by fat. They are also rich in nitrogenous natter, which exists under the form of albumen and casein. Thus constituted, they possess a high 1utritive value, but, like all articles permeated with fatty matter, they are difficult of digestion unless reduced to a minutely divided state before being consumed. The reason of this is easily given. Digestion is effected by the agency of a watery secretion, and where a substance is permeated with oily matter resistance is offered to the penetration of a watery liquid, and it is only by a progressive action upon the surface that it can becone attacked. In a minutely divided state, however, no such obstruction is offered, and now there is only the richness belonging to an article which is largely impregnated with fatty matter. In this state, and if the stomach be not too delicate for them, they form a highly advantageous kind of food, although among the human race 
they enjoy but a limited application as an important or staple support. It must further be remarked that, on account of their fatty constituents, they are prone to become rancid, in the course of time, under exposure to the air.

\section{THE ALMOND.}

This forms one of the most important of the oily seeds. The fruit, like the peach, apricot, plum, etc., belongs to the drupaceous group. The cortical part of it. however, is fibrous and juiceless, and not adapted for eating. The seed or kernel, situated within the shell, and provided with an enveloping reddish-brown skin, is the only edible portion. The skin possesses a somewhat rough and bitter taste. Two rarieties of almond are met with, the sweet and the bitter. They both yield by pressure an odorless fixed oil, which is of a perfectly innocent nature.

Composition of Sweet Almonds.

Emulsin 24.0

Fixed oil $5+.0$

Liquid sugar 6.0

Gum 3.0

Seed coats 5.0

Woody fibre $+\cdot 0$

Water. $3 \cdot 5$

Acetic acid and loss.

0.5

IOO. 00

Composition of Bitter Almonds.

Volatile oil, undetermined.

Emulsin 30.0

Fixed oil 28.0 


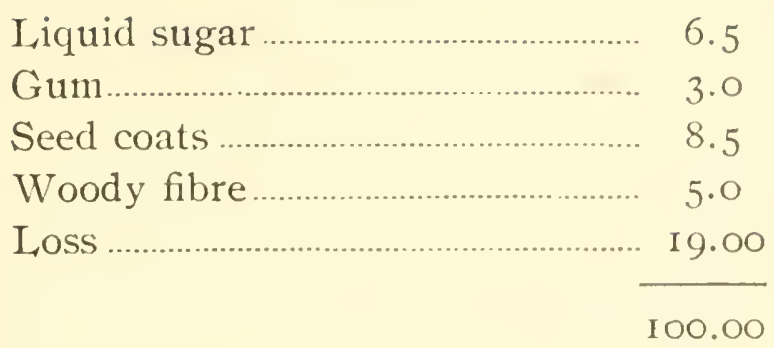

\section{THE COCOANUT.}

The cocoanut is derived from the cocos mucifera, a species of palm, supposed to have been originally a native of the Indian coasts and South Sea Islands, but now found in all tropical regions. The tree grows from sixty to one hundred feet in height, and bears annually about an hundred nuts. The nut consists of a hard shell, containing a white, fleshy kernel, the central portion of which remains unsolidified, and yields the milky juice, which forms an agreeable, cooling beverage. The shell is surrounded by a thick, fibrous husk, which is turned to account for the construction of ropes, matting, etc., and in its natural state the fruit is about the size of a man's head. The fleshy, edible portion contains about 70 per cent of a fixed fat, which is extracted and used uncler the name of cocoanut oil or butter. Its melting point is a little over 70 degrees Fahrenheit. The cocoanut forms one of the chief foods of the inhabitants of Ceylon, the South Sea Islands, the coast of Africa, and many other tropical coasts and islands. It is not only eaten as it comes from the tree, both in the ripe and unripe state, but is also prepared and served in various ways. 


\section{TUBERS AND ROOTS.}

Potatoes.

The potato may be considered as now occupying a place next in importance to the seeds of the cerealia as an article of vegetable food. It is derived from the solanum. tuberosum, a plant belonging to the order solanaceoc, which, including, as it does, the belladonna, stramonium, henbane, and tobacco plants, furnishes some of the most poisonous narcotic products encountered.

It is supposed to be a native of South America, and to have extended thence to North America. It seems to have first been brought to the continent of Europe by the Spaniards, from the neighborhood of Quito, quite early in the sixteenth century, and to have been then cultivated in gardens only as a curiosity. Its introduction into England and Ireland came from North America. The potatoes of Shakespeare are not the same as the potatoes under consideration; but, on the other hand, a product of the batatas edulis, known by the name of the sweet potato. The potato was a third time imported by Sir Walter Raleigh, and, as it then received notice as an article of food, the credit is usually given to him for its introduction among the English. The cultivation of the potato is now widely diffused over the globe, and it seems to thrive in most climates. The part of the plant used as a food constitutes the tuber, which is connected with, or, indeed, forms an exuberant growth of a portion of the underground stem, with which this plant, in common with some others, is provided, in addition to that which grows, as usual, above ground. The potato tuber is sur- 
rounded by a thin, grayish, epidermic covering, and beneath this is another tegumentary layer, in which coloring matter is deposited. The substance of the potato is made up of cells, penetrated and surrounded by a watery albuminous juice, and filled with a number of starch. granules. There are many well-known different sorts of potato met with. They are derived from corresponr. ing varieties in the plant. In the different varieties, notable difference in size, color, and edible qualities, are observable.

Composition of the Potato.

Nitrogenous matter.

Starch

Cellulose

Sugar and gummy matter

Fatty matter.

Pectates, citrates, phosphates and

silicates of line, magnesia,

potash and soda

Water
$2 \cdot 50$ 20.00

I.O4

I.09

O. I I
I. 26

74.00

\subsection{0}

It is thus seen that the potato contains a large percentage of starch. This, indeed, forms its characteristic feature, and renders it applicable for the extraction, that is largely carried on, of starch for domestic and other purposes. While less expensive, there is nothing to show that the starch of the potato differs to any great extent. from the other starchy preparations. in a nutritive point of view. Potatoes require to be cooked to render them fit for eating, and this may be effected either by boiling. steaming, baking, or frying. The heat employer coasulates the albuminous juice contained within and between 
the cells. The starch-granules absorb the watery part of the juice. swell up. and distend the cells in which they are lodged. The cohesion of the cells becomes destroyed. and they then easily separate from each other. leading to the potato easily breaking down into a loose farinaceous mass. Then these clianges are complete the potato is spoken of as being in a mealy condition. IYhen. on the other land. the liquid is only partially absorbecl. and the cells imperfectly separated, the potato remains more or less firm. and is spoken of as close. waxy, or watery. Steaming is a better process for cooking potatoes than boiling. On account of not being attended by the loss that is ocasioned by the latter. When boing is employed, the skin should not be remored, as is nearly ahwas done: for the remoral of the skin farors the extraction of the iuice by the surrounding water. The waste, when potatoes are cooked in their skins only amonnts to : per cent. whereas when they are peeled first, it is about $1 \mathrm{j}$ per cent. A little salt added to the water in which potatoes are boiled tends to prevent the escape (it their saline constitnents.

The potato constitutes a wholesome and agreeable article of food: and one. of which the palate does not easily become tatigued. The amount of nitrogenous matter it contains is too small. howerer. to emable it to form a switahle fond alone. but with articles rich in nitrogchoms mater. as meat. fish. etc., it supplies a usetul and ecomomical alimentary substance. In a mealy state the potati eirjoys easy digestibility: but in a close or watery state it is trying to the digestive powers. and. therefore. when in this condition. should be aroided where delicacy 
of stonach exists. The potato has a high repute for antiscrobutic properties. The concurrent testimony of numerous observers points to its forming a most efficient agent in preventing the occurrence of scurvy. Potatoes become deteriorated upon growing out or germinating. They cease to assume a mealy state on cooking; present a semi-translucent appearance; and possess a rather sickly, sweetish taste. It has been asserted that a poisonous principle, solanin, becomes developed in the buds and shoots of potatoes that are allowed to grow out on keeping. If there be at any time a poison present, it nust be cither insignificant in amount, or be destroyed by the heat to which the potato is subjected before being sent to the table. Exposure to frost also seriously damages the potato. The effect producer is of a mechanical

- nature. The watery juice contained in the cells and intercellular spaces undergoes expansion in the act of freezing, and so leads to a rupture and separation of the cells, and in this way a destruction of the organization of the tuber. Its vitality becomes thus destroyed, and in consequence, it has no longer the power to resist, when thawed, the ordinary changes of decomposition; hence, putrefaction occurs, and advancing, renders the article infit for food.

\section{THE SWEET POTATO.}

The sweet potato is derived from the batatas edulis, a plant which is a native of the Malayan Archipelago, where it formerly grew wild in woods. The plant is now cultivated in most of the warm countries, and furnishes a starchy and sweet tuber, which is prized as an article 
of food in most hot climates. When roasted or boiled, it is mealy, and may be looked upon as forming a wholesome food. It is supposed to possess slight laxative properties.

Composition of the Siveet Potato.

Nitrogenous matter

Starch

I. 50

Sugar I 6.05

Cellulose

I0. 20

Fatty matter

0.45

Other organic matter

0.30

Mineral salts...

I. 10

Water

2.60

$67 \cdot 50$

100.00

\section{CARROTS.}

The garden carrot is derived by cultivation from the. dancus carota, a plant which grows freely in a wild state in fields in some countries. The root of the wild plant is white, slender, and hard, and has an acrid, disagreeable taste, and strong aromatic smell. Is the result of cultivation, the root of the garden variety is thick, fleshy, and succulent and of a red, yellow, or pale straw color, with a pleasant odor, and a sweet, agreeable taste. While young it is very tender, but becomes hard when allowed to grow old. Carrots form a wholesome and useful foorl, for both man and cattle. They are not adapted, howerer, for a weak stomach, being somewhat indigestible and apt to produce flatulence. They are proportionately valuable as they liave more of the outer, soft red, than the central, yellow, core-like part. On account of the sugar present. they admit of a syrup being prepared from them, and 
also yield by fermentation and distillation, a spirituous liquid.

$$
\text { Composition of Citrots. }
$$

Nitrogenous matter.

Starch, etc.

Sugar

I. 3

Fat.

8.4

Mineral matter

6. I

Water

0.2

I.O

83.00

100.00

\section{THE PARSNIP.}

The root of the parsnip, pastinaca sativa, is of a pale yellow color. but otherwise closely resembles that of the carrot, both in general characters and alimentary properties. It is usually served as an accompaniment with salt fish.

Composition of the Parsnip.

Nitrogenous matter ......................... I. I

Starch, etc. ..................................... 9.6

Sugar ............................................. 5.8

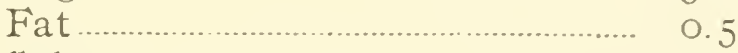

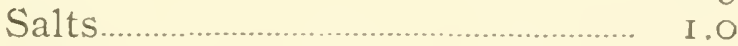

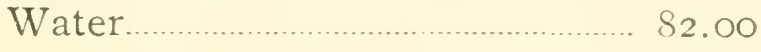

I OO. 00

Parsnips are not only used as a regetable, but a wine is sometimes made from them.

\section{THE TLRNIP.}

Turnips form an agreeable and extensively used vegetable, being either cooked alone or mixed with soups and stews. From the large proportion of water it con- 
tains, its nutritive value is low. The top shoots of such turnip plants as have stood the winter may be gathered, and used as a green vegetable. Those from the Swedish turnip are the sweetest flavored.

Composition of the Turnip.

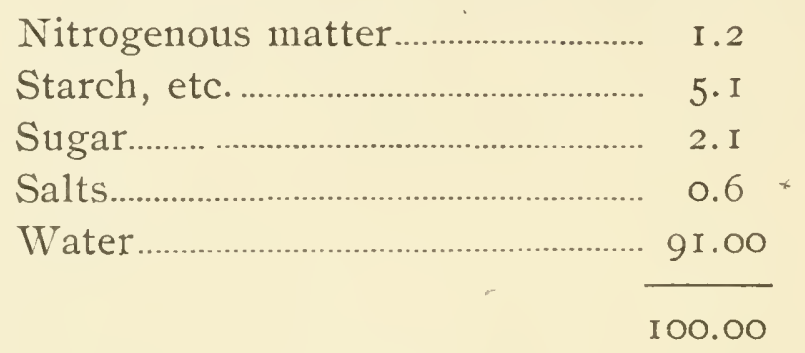

BEET-ROOT.

The common or red beet, bcta vulgaris, which belongs to the family of saltworts, that contain also the spinich, quinoa, etc., and is characterized by the large amount of alkali in combination with an organic acid present in the plants, is a native of the coasts of the Medeterranean, and was cultivated as far back as 1650 . It was then called beet-rave, from the French betterave. The root is usually of an elongated form, like that of the carrot, but in some varieties it assumes more of a turnip-shaped character. The color varies from a deepish blackish-red, to a light red. Beets are extensively grown and employed as food both for man and cattle; and also used as a source of sugar.

\section{RADISHES.}

The common radish is a native of China. The root is either long and spindle shaped, or round and turnip shaped. The color of the exterior varies: there being 
black, riolet, red, and white radishes; but in all the central portion is white. It is usually eaten in a raw state, but is sometimes boiled and served as a vegetable. In composition, the radish closely resembles the turnip.

\section{SALSIFY.}

The salsify, or purple goat's beard, also known as the Oysterplant, is a hardy plant. The root is long and tapering; and becomes by cultivation fleshy and tender. with a white milky juice. It has a mild, sweetish taste, like the parsnip, and is boiled or stewed for the table.

\section{HERBACEOLS ARTICLES.}

These include foliaceous parts, shoots, and stems of plants. They are valuable as articles of food, not so much for the absolute amount of nutritive matter affordedfor, on account of their succulent nature, they contain but a small proportion of solid matter-as for the salts they yield and the variety they give to our diet. By cultivation they have been brought to a very different state from that in which they originally existed. To make them tender and agreeably flavored is part of the art of the gardner, and is effected by quick growth and, in many instances by a partial exclusion of light. The antiscorbutic virtue of this class of regetables is high.

The products of the cabbage tribe are too well known to call for a long description. Looked at in a general way, the varions cabbage plants form a wholesome and agreeable component part of the food of man. As they contain about ninety per cent of water their nutritive value is very low. They are, however, useful for giving 
variety, and for the salts they supply. They labor nuder the disadrantage of being articles of difficult digestion. which renders them unsuited where weakness of stomach exists. 'Their proportion of sulphur is large, and they thus are apt to give rise to flatulence of an unpleasant nature.

\section{SPIN.CH.}

The regetable falling under this name forms the leares of the spinacia oleracea, or garden spinach, a plant supposed to be a native of IVestern Arabia. There are sereral varieties of the plant, and the leares are boiled for use at the table, to be eaten as a green regetable, and are also frequently employed for introduction into soup. It is a wholesome regetable with slightly laxative powers. The Beet family belongs to the same tribe, and the leaves wi the beet are often userl as spinach.

\section{RHLBARB.}

This forms another of the buckwheat tribe, and yields one of the most useful of garden productions. The stalks of the leares, after being peeled, are cooked and eaten precisely in the same way as stewed berries. for which they form a good substitute, if eren they are not to be preferred. Rhubarb occupies, indeed, in an alinentary point of riew, the position of a fruit. but is not so eatable in the raw state. It is also sometimes used for making wine. On account of the oxalate of lime forming a constituent of rlubarb it should be aroided by persons suffering from the oxalate-of-lime diathesis.

\section{CELERI'.}

The common celery, apium graveolens, is a native of Britain, and in the wild state is known as smallage, which 
grows freely in marshy places. In this state it has a coarse, rank taste, and peculiar smell. By cultivation it loses its acrid nature, and becomes mild and sweet. To keep it white or blanched, it is excluded from light, by being earthed up as it grows, the tops of the leaves only being allowed above the ground. Several varieties of the plant are to be met with. Eaten raw, it must undoubtedly be looked upon as difficult of digestion. It is frequently stewed, and is employed also for introducing into soups.

\section{ASPARAGUS.}

The asparagus officinalis belongs to the lily tribe, and in its wild state is a sea coast plant. It is a native of Enrope, and is now extensively cultivated as a garden vegetable. The young shoots form the portion that is eaten, and, by cultivation these have been greatly increased in size, and altered from their original condition. They are nniversally esteemed as a choice and delicate regetable. They contain a special crystallizable principle, called asparagin, which possesses diuretic properties, and gires a peculiar odor to the urine.

\section{ONION.}

The onion, allium cepa, like the asparagus, although differing so much from it in dietetic properties, belongs to the lily tribe of plants. In common with, but to a higher clegree than the other members of the allium species, which includes also the garlic, chive, shallot, and leek, it contains an acric volatile oil, which possesses strongly irritant and excitant properties. Grown in Spain and other warm places, the onion is milder and sweeter than when grown in colder countries. The chief 
uses of the onion reared in our gardens is as a condinent or flavoring agent, and they are also stewed and roasted for the table.

\section{LETTUCE.}

The garden lettuce, lactuca satica, is a hardy plant. of which a great number of varieties exist. It is supposed to be a native of the East Indies. but lias been cultivated in Europe from a remote period of antiquity. The leaves are usually round and spreading and grow near to the ground. The lettuce supplies a wholesome, digestible, cooling; and agreeable food. It is occasionally made use of as a boiled regetable. It contains a milly juice. especially when the plant has been allowed to run to flower, which possesses a mild soporific property.

\section{CRESS.}

The common or garden cress, lepidium sativmm, is a native of the East, but has been under cultivation for hundreds of years. The young leaves are used as salad. and they possess a pungent and agreeable flavor. It ranks as one of the principal of the small salads. and a variety with curled leaves is especially esteemed.

\section{IVATERCRESS.}

The watercress, nasturtimm officinalc, is a creeping plant, which grows in slow-running streams, and thrives best on a bottom of sand or gravel. It is a native of almost all parts of the world, and forms a farorite and wholesome article, which is seldom out of season. There are two varieties-the green and bromn. 


\section{FRUITY PRODUCTS CONSUMED AS \\ VEGETABLES. \\ CUCUMBER.}

The common cucumber, cucumis satious, is a native of the South of Asia, but has long been cultivated in all civilized countries. It furnishes a fleshy fruit, which forms an edible product. It is grown both in the open air and under glass, the fruit varying in size, tenderness, and flavor, accordingly; that which is forced or grown quickly possessing choicer qualities than that which is grown slowly. Cucumber in the raw state must be looked upon as a cold and indigestible article. Young cucumbers are pickled in rinegar and condiments, and in this state they form an agreeable relish at a meal, and serve to give zest to other food.

\section{TOMATO}

The tomato, or love-apple, solanum lycopersicum, is a native of South America. The ripe fruit is used in various. ways, and has an agreeable acidulous taste. It is more, perhaps, as a relish, than for its nutritive value that it is useful, and its popularity increases every year. In the unripe state it makes an excellent pickle. It is also extensively used in the manufacture of tomato ketchup.

\section{MUSHROOMS.}

The agaricus campestris constitutes the common edible mushroom. It is found springing up spontaneously in our woods and pastures during the warm seasons, and is also cultirated in beds of prepared horse manure, and 
thence obtainable all the year round. It is a native of most of the temperate regions of both hemispheres. It produces a spreading filmentons or thread-like underground structure, called the mycolium or sparn. From this, little tubers spring: which rapidly enlarge, and grow into a stalk, bearing at its summit a rounded head, which, in a short time, expands into a pilens or cap. This, which forms the edible portion, constitutes the fructification, and presents upon its under surface a number of parallel plates or gills, that bear the sporules of the fungus.

Mushrooms are employed for flavoring, and as. an occasionai delicacy, rather than as a common article of food. Although difficult of digestion, and, therefore, not adapted for the weak stomach, yet by most healthy persons they may be consumed without proving hurtful. They are eaten in the fresh state, either broiled, baked, or stewed, and are also preserved by pickling. The young or button mushrooms are used for the latter purpose.

The rcsemblance hetween mushrooms and toadstools is so close, that serions consequences have arisen from the wrong fungus having been eaten. The effects produced by the poisonous fungus are of a narcotico-acrid nature: sometimes coma has been noticed as the predominant symptom, at other times the symptoms have been allied to those of cholera.

\section{TRUFFLES.}

The turffle forms a sulbterraneous fungus, which never appears above the surface. There are three varietiesthe black, white, and red or violet. The latter is rare, and of the two former the black is held in by far the 
higher repute. The white, indeed, is considered of comparatively little value. To be in perfection, truffles should be quite fresh, much of their aroma being lost by keeping. Truffles are considered, in the Old IVorld, an article of the greatest delicacy. Their firm and toughish consistence renders them indigestible, but they are esteemed for the salie of their peculiar aroma. They are seldom eaten alone. They are often used as a stuffing, and to flavor gravies and sances.

\section{FRUITS.}

The term fruit, in botanical language, signifies the seed, with the surrounding structures, in progress to, or arrived at, maturity. In a popular and dietetic sense, it has a more limited signification. and refers in a general way only to such product when used in the manner of a dessert. Botanically, wheat, peas, beans, etc., constitute fruits, but poptilarly the term is restricted to articles like apples, pears, plums, peaches, cherries, grapes, etc.

Fruits consist of two parts, the seed, and what is technically called the pericarp. The latter comprises that which surrounds the seerl, and is composed of the eatable portion, the external integument or skin: the inner coat or shell: and the intermediate part, which generally possesses a more or less fleshy consistence. It is the intermediate part which forms the edible succulent portion of the fruit.

The fower, and thence the fruit, is formed from modifications of the leaf. and in an early stage the fruit is srech, and exhibits much the same chemical composition and general comportment as the leaf. It is only as ma- 
turity adrances that its special characteristics become developecl. It first, like other green parts of the plant, it absorbs and decomposes the carbonic acid of the atmosphere under the influence of light, liberating oxygen and assinilating the carbon. During its progress it increases more or less rapidly in bulk and weight: and, as it approaches maturity, it loses its green color, and becomes brown, yellow or red, and no longer acts on the air like the leares. but on the contrary absorbs oxygen and gives out carbonic acid. As this process advances, some of the proximate principles contained in the unripe fruit, particularly the regetable acids and tannin, in part disappear, apparently by oxidation, and thus, it becomes less sour and astringent. At the same time the starch undergoes transformation into sugar; and the insoluable pectose, into pectin and other soluble substances of allied composition and having more or less of a gelatinous character. The fruit in this way arrives at a state of perfection for eating. Oxidation, howerer, still adrances, and now, the sugar and remaining acid become destroyed, giving rise to the loss of flavor which occurs after the full ripened state has been attained and deterioration has set in. Finally, if the changes are allowed to pursue their ordinary course, the pericarp undergoes decay, and the seed is set free.

The agreeable taste of fruits partly depends on the aroma, and partly on the existence of a due relation between the acid, sugar, gum, pectin, etc., and likewise between the water and the soluble and insoluble constituents. Luscious fruits like the peach, which seem to melt in the mouth, contain a very large proportion of 
soluble substances. A due proportion of gum, pectin, and other gelatinous substances, serve to mask the taste of the free acid, if present in a somewhat large propertion as compared with the sugar. Such is the case with the peach, apricot, and greengage, which contain but a small amount of sugar as compared with the free acirl, but a large proportion of gum and pectous substances. The sour taste of certain berry fruits, as the currant and gooseberry, arise from the presence of a considerable quantity of free acicl, with only a small amount of gum and pectin to disguise it. By cultivation, the proportion of sugar may be increased in fruits, as is shown by the difference existing between the wild and cultivated strawberry and rasplerry.

Fruit forms an agreeable and refreshing kind of food, and, eaten in moderate quantity, exerts a favorable influence as an article of diet. Its proportion of nitrogenous matter is too low, and of water too high, to allow it to possess much nutritive value. It is chiefly of service, looking at the actual material afforded, for the carbohydrates, regetable acids, and salts it contains. It en joys to a high degree the power of connteracting the unhealthy state found to be induced by too close restriction to dried and salted provisions. The preserved juice acts in this way equally as well as the fresh fruit, and the juice of certain fruits, the lemon and lime, for instance, as is -well known, is specially and largely used for its antiscorbutic efficacy.

While advantageous when consumed in moderate quantity, fruit, on the other hand, proves often injurious if eaten in excess. Of a highly succulent nature, and 
containing free acids and principles prone to undergo change, it is apt. When ingested out of due proportion to other food, to act as a disturbing element, and excite clerangement of the alimentary canal. This is particularly likely to occur if eaten either in the muripe or overripe state: in the former case, from the quantity of acid present: in the latter, from its strong tendency to ferment and rlecompose within the digestive tract. The prevalence of stomach and bowel disorders, noticeable during the lieight of the fruit season, affords proof of the inconvenience that the too free use of fruit may sive rise to.

The effect of fruit is to diminish the acidity of the urine. The alkaline regetable salts which it contains becomes decomposed in the system, and converted into the carbonate of the alliali. which passes off with the mine. By virtue of this result the employment of fruit is calculated to prove adrantageous in gout and other cases where the urine shows a tendency to throw down a cleposit of lithic acid.

\section{THE IPPLE.}

The apple, pirms malus, and of which there are now very munerous rarieties, is derived by cultivation from the wild crab, a mative of Britain, and other parts of Europe.

The apple forms one of the most useful and plentiful of iruits. It is introluced into tarts and puddings. besides being emplored at the dessert table and made into sance, preserve. and jelly. It also furnishes the fermented beverage called cider. Verjuice is the fermented juice of the crab-apple. 
Composition of Apples.

Soluble matter:-

Sugar.

Free acid (reduced to equivalent in malic)

Albuminous snbstances.

O. 22

Pectous substances, etc.

Ash

0.44

Insoluble matter:

Seeds

0.38

Skins, etc.

I. 42

Pectose.

I. 16

Water

85.04

100.00

THE PEAR.

The pear, pyrus communis, like the apple, flourishes pretty much everywhere. There is a large number of varieties of the pear. The fruit is chiefly used for dessert, but is also stewed and preserved as other fruits are.

Composition of Pears.

Soluble matter:-

Sugar.

Free acid (reduced to equivalent. malic acid)

Albuminous substances

7.000

Pectous substances

Ash.

0.074

0.260

$3.28 \mathrm{I}$

Insoluble matter:-

0.285

Seeds.

0.390

Skins, etc

3.420

Pectose.

I. 340

Water. 
A TREATISE ON FOODS.

moderate quantity. Prunes are used for their laxative effect.

\section{THE CHERRY.}

The common cherry, cerasus duracina, is supposed to have been a native of Syria and other parts of Western Asia. The different varieties vary greatly in color. Cherries, like plums, require to be eaten in moderation, on account of their tendency to disorder the bowels. In the unripe and unsound state they are particularly apt to do so. The stones of cherries should never be swallowed.

\section{THE PEACH.}

The peach, amygdalus persica, is a native of Persia and the North of India, and is now grown in all temperate climates. It thrives very freely and produces most plentifully in the United States. The peach forms one of the most luscious and choicest of fruits. The skin is downy or velvety, and its color varies from a dark reddish violet through many shades of crimson, green or vellow, to the clear white. The composition shows that the peach is notable for the small quantity of saccharine matter it contains in comparison with all other kinds of edible fruits.

Composition of the Peach.

Soluble matter:-

Sugar.

Free acid

Albuminous substances

Pectous substances, etc.

Ash
I. 580

0.6 I 2

0.463

$6.3 \mathrm{I} 3$

0.422 


\section{Insoluble matter:-}

Seeds

Skins, pectose, etc.

Water

I 00.000

\section{THE OLIVE.}

The olive tree, olea europoea, is supposed to be originally a native of Greece, but it has long been naturalized in other countries. The fruit in the ripe state is black, and its fleshy part abounds in oil, which is expressed and used as salad oil and for cooking. The ripe fruit has a strong and, most persons would consider, a disagreeable taste.

\section{THE DATE.}

The date is derived from the phoenix dactylifora, the date palm or palm tree of Scripture, a native of Afi ica and parts of Asia, and now brought into cultivation in parts of Europe. Dates, both fresh and dried, form the chief food of the Arabs. Cakes of dates pounded and kneaded together into a solid mass constitute also the store of food, called the "bread of the desert," provided for caravans on their journey through the desert. The fruit is of a drupaceous nature, and the fleshy part contains about 58 per cent of sugar, accompanied by pectin, gum, etc.

\section{THE GRAPE.}

The grape vine, vitia vinifera, is indigenous in the far East. It produces fruit in the form of a globular or oval berry with a smooth skin. The color of the fruit is very 
moderate quantity. Prumes are used for their laxative effect.

\section{THE CHERRY.}

The common cherry corasus duracina, is supposed to have been a native of Syria and other parts of Western Asia. The different varieties vary greatly in color. Cherries, like plums, require to be eaten in moderation. on account of their tendency to disorder the bowels. In the unripe and unsound state they are particularly apt to to so. The stones of cherries should nerer be swallowed.

\section{THE PEACH.}

The peach. amydalus porsica, is a native of Persia and the North of India, and is now grown in all temperate climates. It thrives rery freely and produces most plentifully in the United States. The peach forms one of the most luscious and choicest of fruits. The skin is downy or relrety, and its color varies from a clark reddish riolet through many shades of crimson, green or rellow, to the clear white. The composition shows that the peach is notable for the small quantity of saccharine matter it contains in comparison with all other kinds of edible fruits.

Composition of the Peach.

Soluble matter:-

Sugar

I. 5 S०

Free acid

0.6 I 2

Albuminous substances

Pectous substances, etc. 
Insoluble matter:-

Seeds

Skins, pectose, etc.

Water

I 00.000

\section{THE OLIVE.}

The olive tree, olea curopoea, is supposed to be originally a native of Greece, but it has long been naturalized in other countries. The fruit in the ripe state is black, and its fleshy part abounds in oil, which is expressed and used as salarl oil and for cooking. The ripe fruit has a strong and, most persons would consider, a disagreeable taste.

\section{THE DATE.}

The date is derived from the phoenix dactylifera, the date palm or palm tree of Scripture, a native of Af 1 ica and parts of Asia, and now brought into cultivation in parts of Europe. Dates, both fresh and dried, form the chief food of the Arabs. Cakes of dates pounded and kneaded together into a solid mass constitute also the store of food, called the "bread of the desert," provided for caravans on their journey through the desert. The fruit is of a drupaceous nature, and the fleshy part contains about 58 per cent of sugar, accompanied by pectin, gum, etc.

\section{THE GRAPE.}

The grape vine, vitia vinifera, is indigenous in the far East. It produces fruit in the form of a globular or oral berry with a smooth skin. The color of the fruit is very 
rarions. fron white. yellow, amber, grenn. and red, to black. Hundreds of varieties are described in works on the culture of the plant. The grape is one of the n110: useful and highly esteened imits. The skin and seeds are indigestibie and shonld he rejected. but the juicy pulp possesses wholesonue, mutritions. and refoigerant properties, and may usually be safely taken by the inralid. If eaten freely the fmit exerts a dimetic and laxatire action. The juice of ripe grapes contains a considerable quantity of grape-sugar. small quantities of a glutimous substance and of extractive matter. bitartrate of potash. tartrate of lime. a little malic acid. and other ingredients suspended or dissolved in water.

Composition of Grapes.

Soluble matter:-

Sugar.

I $3.7 \lesssim 0$

Free acid

I. O $=0$

Albuminous substances

0.832

Pectous substances, etc.

0.495

$A s h$

$0 . ; 60$

Insoluble matter:-

Seeds and skins

$\therefore .592$

Pectose

$0.9+1$

Irater

79.997

I00.000

\section{THE STRAMEERRI.}

The common rood strawberry is indigenous in about all temperate climates. The products which hare been obtained by cultivation from this plant rank among the choicest and most tempting of smmmer fruts. and aftord 
A TRFATISE ON FOODS.

an example of one of the greatest trimmpls of the sardener's art. The fruit of the different plants raries greatly in size and keeping qualities. The wild stramberry has only about one-halt as much sugar as the tame cultivated rarieties.

Composition OF STRMWBERRES.

Soluble matter:-

Sisgar

Free acid $7 \cdot 575$

Albuminous substances

1. 133

Pectous substances, etc.

0.359

Asli

O. I 19

0.450

Insoluble matter:-

Seeds. skins, etc.

1.960

Pectose

0.900

IVater $57 \cdot+74$

100.000

THE MULBERRY.

The black or common nulberry, morms nigra, is a natire of Persia. but is supposed to hare been introduced into Enrope by the Romans. The fruit is of a purplish black color. with dark red juice, fine aromatic flaror. and acidulons, and sweet taste. It possesses wholesome. refrigerant and slightly laxative properties. and is highly esteenned for dessert: an excellent preserve and an agreeable wine are made from it.

\section{Conposition of Mulberries.}

Solid matter:-

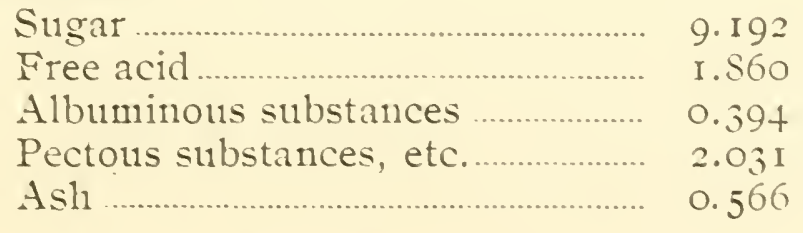


Insoluble matter:-

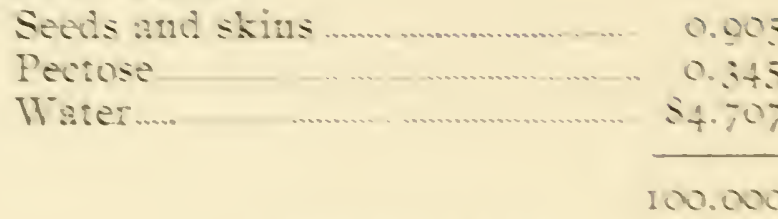

\section{THE MIELON.}

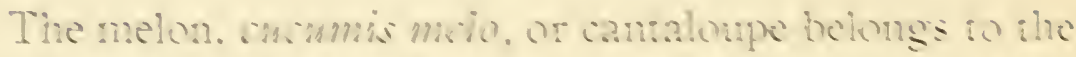
sourd wibe. The frute varies somewhat in stro. color. and the character of the rind. In some the rind is smowth and thim. in orhers thick and warts. and cracked in a

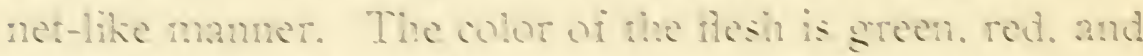
vilom: It is catcin cither with sugar as dessert. or with

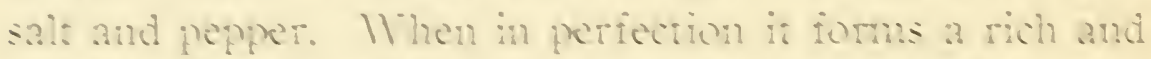

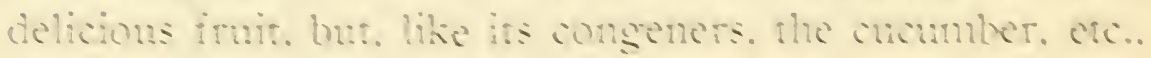

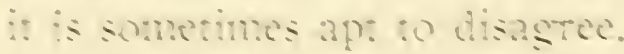

\section{THE PIXE- IPPLE.}

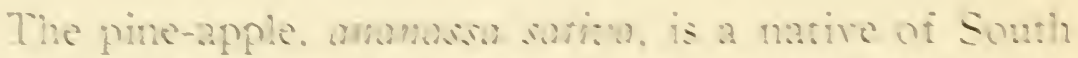

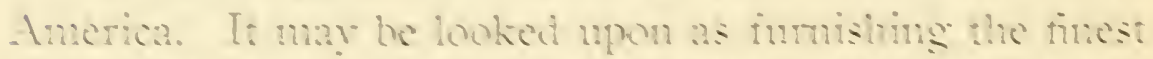

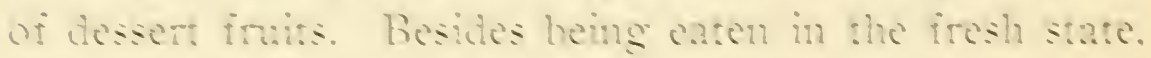

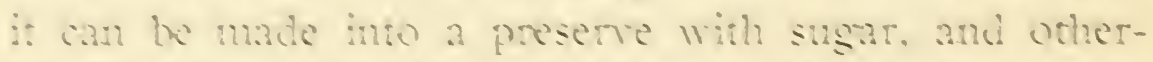

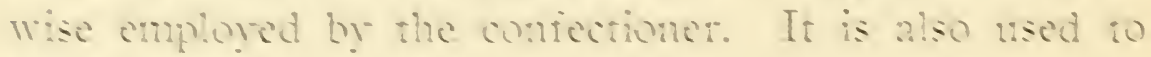
Anvor rum.

\section{THE FIC.}

The common fige, fow comber is a native of tsia and Barbary: The vartetics cultivated are munerous, and the color of the frute of some is binkh-hack, of whers, red. purple. sweeri, ychow, or white. The frut is pear-shaped. and consists of a pulpy mass comoming many sodthe boties. The amount of sugar present is excedingly larse. Grown in wame countries they hom a rich and hustous 
fruit. Figs are largely imported in a dried and compressed state. If frecly eaten they are apt to irritate and disorder the stomad and bowels.

\section{THE, PLANTAIN AND BANANA.}

The plantian, musa paradistaca, is a native of the East Tudlies, hut is now diffused all over the tropical and subtropical regions of the globe. It is so called on aceount of having been supposed to have fumbled the fruit which tempted lise in Paratelise. The banana, muse sapientum, appears to be mly a variety of the plantain. bearing smaller and more delicately flavored fruit. Tts name is due to its having formed the chicf food of the Brahmins or wise people of ludia. They both constitute exeect. ingly procluctive plants, and it is asserted that an extent of ground which would only grow wheat enough for the support of two persons would maintan fifty if cultivated with the plantain. Plantains and lananas form inportant and valuable articles of food to the inhabitants of many tropical regions. They cren afford in some localities the chief alimentary support of the people. The fruit occurs in large humches or clusters. Which weigh nearly fifty pounds. On stripping off the tegumentary part. a softish core is met with. Which is chiefly fartmaceots in the moripe, and sacelatrine in the ripe state: the starch hecoming comverted, it is stated, during maturation, first into a mucilaginous substance, and then into sugar. Plantain meal is prepared hy powdering anci sifting the dried core of the plantain while in the green or umripe state. It has a fragrant odor, and a bland taste. like that of common wheat flome. It is said to be easy 
of digestion, and to be extensively employed in some countries as the food of infants, children and invalids. The larger proportion of it consists of starch, but it also contains a certain percentage of nitrogenous matter, and is, therefore, of higher alimentary value than the starch preparations, as sago, arrowroot, etc.

Composition of the Pulp of Ripe Bananas.

Nitrogenous matter 4.820

Sugar, pectose, organic acid, with traces of starch. I 9.657

Fatty matter

0.632

Cellulose

0.200

Saline matter

0.791

Water.

73.900

100.000

\section{SACCHARINE PREPARATIONS.}

Sugar forms an important alimentary principle, and is met with widely, and in certain cases largely, among vegetable products, from some of which it is extracted for use. It also constitutes under the name of lactin, one of the ingredients of the animal food provided by rature for the support of the young mammal, viz., milk. Sugar was known to the ancient Greeks and Romans, and its manufacture is said to be of the greatest antiquity in China. Sugar evidently contributes towards force-production in the body, and, likewise, as is shown by ample evidence, towards the formation and accumulation of fat. Being of a soluble and diffusible nature, it needs no preliminary digestion for absorption, and, therefore. sits lightly on the stomach. It is, however, in some dyspeptics 
apt to undergo the acid fermentation, and give rise to preternatural acidity of the stomach, and likewise fatulence. A popular notion prevails that sugar has a tendency to injure the teeth. This is due to the acid fermentation in the stomach after swallowing.

Besides employment as a daily article of food, sugar constitutes the base of a variety of products of the confectioner's art. On account of its antiseptic virtue, it is also extensively used as a preservative of other sui)stances. It is chiefly vegetable products, as fruits, etc., that it is employed for preserving, but animal substances can be equally well kept by the influence it exerts in this direction.

\section{HONEY.}

Honey may be most conveniently referred to here, although not an article standing in precisely the same position as the other products included in the group. It is an article collected by the bee for its own use. which man takes possession of and consumes instead. It is an exudation from the nectariferous glands of flowers, which the bee sucks up and passes into the dilation of the oesophagus forming the crop or honey-bag. From this it is afterwards disgorged, probably somewhat altered in its properties by the secretion of the crop, and deposited in the cell of the honeycomb. Honey is a concentrated solution of sugar, mixed with odorous, coloring, gummy, and waxy matters.

\section{FARINACEOUS PREPARATIONS.}

Farinaceous or starch matter is a product which is yielded by the vegetable kingdom only. Here, however, 
it is widely, and often very largely met with. It occurs under the form of little gramular bodies (starch-granules) lodged in the regetable tissues, but readily susceptible under appropriate treatment. of isolation. These granules possess a distinctly organized construction, and are made up of a series of superposed layers. the outermost of which is the thichest and hardest. Thus are produced the concentric lines which are risible when the sranule is submitted to microscopic examination. andi which are arranged around a spot which is called the hilum. The sranules from different sources present distinctive teatures as regards, size. form. and appearance. which may be recognized with the aid of the microscope.

Starch forms an important alinentary article. Being devoid of nitrogen, it can contribute only towards force and fat production. The hardness of the extemal enrelope renders the granule in its original state difficult of digestion-and digestion, which involves transformation into sugar. must oceur before absorption and utilization can ocur. On this acount. When starch is consumed in the raw state. more or less of it passes off with the undigested residue from the almentary camal. By boiling. or otherwise exposing to heat, the granules rupture and becone far more easily attacked by the digestive juices. Starchy matter, therefore. should be subjected to cooking before being consumed.

There are various starch preparations in common use, such as sago, cassava. tapioca. arrowroot, salep. ete.

\section{BEVER.GES.}

A supply of water under some shape or other is one of the essential conditions of life. It is just as neediul 
as solid matter. It not only enters largely into the construction of the different parts of the organism, but is required for various purposes in the performance of the operations of life. Without it, for instance, there could be 110 circulation nor molecular mobility of any kind. It forms the liquid element of the secretions, and thereby the medium for dissolving and enabling the digested food to pass into the system and the effete products to pass out. A constant ingress and egress are occurring; and the former requires to stand in proper adjustment to the latter. ['nder ordinary conditions of exercise and temperature it may le estimated that about five pints of fluid pass off through the kidneys, skin, hungs, and alimentary canal from an average sized adult in the course of the twenty-four hours, and this has to be replenished from without. But it is not necessary that this amount should be drunk. A large proportion of our solicl food, in many cases as much as $: 0$, so, or 90 per cent consist of water. The loss going on, however, represents such a fluctuating product dependent on exercise or work and the temperatrre to which the body is exposed that great variation must ensue in the annotint of fluid consumed.

If a plain and wholesome liquid be chunk the error is not likely to be committed of taking too much. After compensating for the loss by the skin, and with the breath. the surplus passes off through the minary channel, and it is desirable that this surplus should amply suffice to carry off the effete products forming the solid matter of the urine in a thoroughly dissolved state.

Mater constitutes the essential basis of all our drinks. taken purely as such. The liquids consumed are of 
various kinds, but water is the element physiologically and indispensably required. Water is derivable from various sources, and is denominated accordingly as. rain water, spring water. well water, river water. distilled water. etc.

\section{TEA.}

Tea constitutes the dried leaves of a plant belonging to the genus that of limacus. It is indigenous in China. Cochin China. Tapan, and India. Tea is consumed under the form of infusion. Which should be prepared by pouring boiling water on it, and allowing it to stand a short time. If boiled, a loss of its characteristic flavor occurs through the dissipation of the aromatic principle, which is rery rolatile. Tea contains essential oil, chlorophyll. wax, resin, gum, tamnin, thein. extractive matter, coloring substance, albumen, fibre and ash.

\section{COFFEE.}

Coffee beans constitute the seeds found within the fruit of the coffic arabica, a small tree belonging to the tribe coffuceos. which is indigenous in Southern - Abyssinia. The frut forms a succulent berry similar in appearance and color to a small cherry. Each berry contains usually two seeds. forming the coffee bean of commerce. surrounded by a parchment-like enrelope and fleshy pulp.

The chief constituents of coffee are of the same nature as tea. A rolatile oil which gives to coffee the aroma it possesses, and is dereloped by the process of roasting: The amount of it is less than that existing in tea. An astringent matter constituting a modification of tannin 
and called caffee-tannic and caffeic acids. It is present in much smaller quantity than tannic acid in tea, and amounts to about 5 per cent in raw coffee. Caffein-this principle is identical with thein. The amount of it in coffee varies considerably.

Composition of Coffee.

Cellulose 34 .

Water. I 2 .

Fatty matter I 3 .

Glucose, dextrin, vegetable acid, I 5.5

Legumin, casein, etc. IO.

Cliloroginate of potash and of caffein 5 .

Nitrogenized structure 3 .

Caffein 0.8

Essential oil $0.00 \mathrm{I}$

Aromatic essence. 0.002

Mineral substances 6.697

I 00.000

\section{COCOA.}

Cocoa constitutes a product derived from the seeds of the theobroma cacao, a tree indigenous in South America, Mexico, and the West Indies. The term cocoa, as applied to this product, must not be looked upon as implying that it has any relation to the well-known cocoanut. Cocoa is characterized, and distinguished from tea and coffee, by the larger amount of fatty and albuminous matters it contains, these principles averaging as much as about 50 and 20 per cent respectively in the manufactured article. 
Composition of Cocon.

Cacao butter 50

Albumen and nitrogenous matter, 20.

Theobromin

Starch with traces of sugar ............ Io.

Cellulose

2.

Mineral matter

Water

While highly nutritive its richness in fat renders cocoa oppresive to a delicate stomach.

As a closing article to the foregoing food analyses. we will review milk and eggs.

It happens that an article, riz., Milk, is produced by the operations of nature for the special purpose of sustaining life during an early period of the existence of the mammalian animal. Such an article may be taken as affording a typical illustration of natural food. Now. we find on looking to its composition that it contains the following alimentary principles:

Nitrogenous matter (casein principally, and in smaller quantity some other forms of albuminoid matter).

Fatty matter (butter).

A carbohydrate (lactin).

Inorganic matter, comprising salines and water.

The $c g g$ also stands in an analogous position. As all the parts of the young animal are erolred from it, it must needs represent the material, or contain the suitable principles, for the development and growth of the body, and the same groups of principles are to be recognized that exist in milk. althongh in the case of one of them it is 
only present to a somewhat minute extent. (1) Nitrogenous matter is largely present under the form of albumen. both in the white and rolk. ( $\because$ ) Oily matter is contained in the volk. (:3) Saccharine nutter, a principle belonging to the carbohylrate group, is to be detected. but only, it must be mentioned. to a sparing extent. in which the composition of the ege differs notably from that of milk. $(-t)$ Inorganic matter. consisting of salines and water. completes the list. and for the saline matter required. that helonging to the shell is drawn mpon as the process of inculation proceeds. Is pointed out before there is an insufficiency of mineral matter in the contents of the egs muless the shell is taken into acconnt.

I H.INDY TABLE OF VARIOLS FOODS.

Linseed cake,

Decorticated cotton cake,

Undecorticated cotton cake,

$\begin{array}{rrr}2 S .3 & 41.3 & \text { IO.O } \\ \text { HI.O } & 57.0 & \text { IO.O } \\ 24.0 & 46.9 & 8.0 \\ 25.5 & 45.5 & 2.0 \\ 22.4 & 52.3 & 2.5 \\ \text { I I.0 } & 69.2 & 2.0 \\ \text { I0.0 } & 68.0 & 7.0 \\ 6.9 & 77.0 & 4.0 \\ \text { I } 4.0 & 76.0 & 4.0 \\ \text { I } 4.0 & 50.0 & 3.5 \\ \text { I 2.0 } & 60.9 & 6.0 \\ 9.5 & 6.6 & 2.5 \\ 9.0 & 76.0 & 3.0 \\ 26.0 & 60.0 & 4.0 \\ \text { I 5.3 } & 29.2 & 3.3 \\ \text { I } 4.9 & 34.3 & 3.5 \\ \text { I 3.4 } & 29.9 & 3.2 \\ \text { S.02 } & 41.3 & 2.0\end{array}$

Bean meal,

Pea meal,

Rye meal,

Indian corn,

Rice meal,

Palm nut meal,

Wheat bran,

Oats,

Barley:,

Malt,

Malt culms,

Alsike clover in blossom,

White clorer in blossom,

Red clover in blossom,

Common meadow hay, 
Pea straw, $6.05 \quad 35.2 \quad 2.0$

Oat straw.

$2.5 \quad$ is.2 2.0

Potatues.

Carruts.

$2.0 \quad 21.0$

0.3

Turnips.

1.5

7.0

o. 2

Mangels,

1.0

5. I

O. I

2.0

S.

o. :

\section{FEEDING FOR WINTER EGGS.}

I have had my troubles in getting hens to produce egss during the cold months of the rear. For three solid years my money was placed on a hong-shor that never salloped home. Durmg those three years the feed store proprietor hanked the good currency that seemed to have struck a natural tendency to travel from my acount to his. I learned gradually the meaning of a balanced ration-as it senerally works itself ont this means the maintaining of the feed store owners balance on the credit side of the hank ledger. It sommled real interesting to my unthinking and mreasoning intellect while the varions feed men minolded to me the merits of their batanced hen feeds. The compusition usually ran about thus:

Composition of "OuR" Mined Hea Feed.

Sunflower seeds,

Millet.

Indian corn.

Kaftir corn.

Sweet corn.

Whole corn.

Cracked corn,

ITheat screenings.

Barley.

Oats.

Buckwheat . 
Looked good to me then, and seemed to be cunningly thought out, but after a prolonged study of foods and their analyses it clid not look nearly so good to my awakening "thinker." In three years, with an average of a hundred and fifty hens to winter, my balance shrunk something around five hundred dollars, and the egg production was nil.

It is really amazing the way nou-producers of the hen tribe can eat up your good money, and, as a mere incident, it may be mentioned as equally amazing, the very small amount of knowledge the average person has of the constituents of food substances.

What started me to thinking all the feed men were away off in their calculations of furnishing an egg producing food, and I honestly give them creclit for really trying to put up such a food, was that I purchased a corv. It was not long after that, when the cold weather set in, that it was noticeable the cow was producing milk just as plentifully tied up in the sled eating a combined clover and timothy hay, with also a little corn fodder for variety, and a couple of quarts of bran more as a laxative than anything else; producing milk just as rich in butter fat as she had during the warm weather. If, thought I, this cow can produce milk abounding in a good grade of fat from nothing but clover and timothy hay, or from nothing but ordinary pasture, why the deuce cannot hens produce eggs from the same substances.

Then began a frantic search for knowledge. Foods haunted me by day and disturbed my sleep o' niglits. The search for knowledge, with such a goal as winter egg production for its objective, was certain to result in 
success if dietetic principles were applied to the hen as intelligently as to the human being. The hens were evidently both willing and anxions to help me along. They had long since becone wearied of balanced rations which passed through them without stopping to even suggest the ego proposition. That study of foods and the success attending it have led to the writing of this treatise on foods. so that all who run may read. and. incidentally. reap a profit from any breed of chickens they may happen to be keeping:

Of conse many of my clollars had gone to the varions wise nen of the East. Who had hooks to sell at one to five dollars. Which said books told one how to put in lots of one's valuable time doing a foolish piece of lahor called "sprouting." or "processed" oats. Likewise many other men had "systems." but as you are all familiar with them and the wonderful results they are said to accomplish. on paper. it will not be necessary to "strain your system" by a recapitulation. One of the very real wise men is attempting to patent a growing grain crop. There is a chance for your. my dear reader. get out a patent on the potato crop-that will beat Armom in his wheat corner. I charge you nothing for the adrice.

To the feed store men I said: Out upon you: awa! with your bone meals: away with your beef scraps: they enter the hen as such. pass through her as such and are thrown on the manure pile practically nnchanged from the state in which eaten, making. I agree, a very good. but a rery" expensive tertilizer. \$:..人 to $\$: 3.00$ per hundred pounds for fertilizer. Whew, no wonder I wäs growing poor quite rapidly. 
Dicl your. my reader, ever feed a com beef scraps to produce milk? Did you ever feed a cow bone meal to increase the production of butter fat? Not $11 n \mathrm{ch}$, you say: the com" (loes quite well on pasture and salt, and she does rot add grasshoppers and bugs to her diet eren in warm weather.

My hens were finally placed on the following mixed (liet, which from a dietetic point of view struck me as being about right. It is right.

Whole corn for breakfast and supper.

Vhole rye for noon meal.

Bran and linseed meal, with salt, in a common box.

Cut clover and timotly hay, soaked orer night in Narnl water.

For the drinking crocks the beverage from the soaked hay.

That is all there is to the feeding and it makes hens lay so fast it will keep you busy picking up the eggs any winter day. The mash is wet, after being well mixed together in a dry state. Four quarts of wheat bran and a quart and a half of linseed meal will suffice as "hopper" food for $\%$ to 100 hens for $2+t$ hours. The way chickens will eat of that cut hay and mixed mash will make you sit up and take notice. The way they will repay you tor giving them a rational food supply will tickle you.

Look back at the composition of the egg and you will understand the egs production. Thirty per cent of fat-the yolk all fat-that is where your corn and linseed meal come in, the rye very rich in the other necessary constituents "balances" the diet, and the green stuff is nature's preserved food-stuff for the cold weather. The 
hay by soaking over night is broken down and the tough texture softened; a manufacturer of any of our so-called breakfast-foods, would no doubt speak of this hay as "pre-digested"- and with reason, as it is already softened and moistened ready to undergo instant transformation the moment it reaches the hens crop. There is no labor preparing this hay. Simply cut it into short lengths in a cutting box, throw some into a 1 -quart pail and pour water on it, and you have green food for 100 hens for a full day. Dilute the water from the hay with sufficient more water to go round your flock, thus they get all the good the hay possesses. I feed it in a box the same as the mash. The cost, figuring about five pounds of hay to a bushel, with hay at $\$ 9.00$ per ton (that's what I paid for mine this fall) will come to about two and a half cents per bushel. That beats even your much advertised 10 cents per bushel stuff, and you do not raise a grain crop the whole of your spare time. Iou must, however, to get good results, never let up on the lice part of your labor. Also keep good grit, oyster shell and charcoal before the hens at all times. In the past I have paid a robber's price for alfalfa meal, and it never was a tenth as satisfying as common cut hay.

My coop is built with a sloping flat roof. sides of one inch boards of any old kind of lumber. corered with a one-ply brand of roofing paper. Three varieties of chickens-B. P. Rocks. White Leghorns and R. I. Redsdo equally well in producing hen fruit on the above feed. There is an allowance of about four square feet for each hen and they are never out of cloors from Fall unti! Spring. The writers for poultry papers who dope out 
the statement that each hen ought to have, and must have, not less than ten square feet of space to root around in, are about as close to facts in this matter as they are in matters of feed. Twenty of my hens will lay equally as well with four square feet as they will with twenty square feet, and, I have no doubt, even better. One long house separated into pens by the use of poultry netting fills the bill. My hens are not tempted to acrobatics by suspended cabbage plants. All they do is eat the right food and lay eggs. There is no artificial heat, and there are no so-called automatic non-freezing hot water fountains, as nature never, to my knowledge, provided or intended such contraptions.

When buying your feed get the whole corn. You can rest assured then that you are not paying a high price for ground up corn-cobs and the floor sweepings. All experiments prove whole corn just as valuable as the cracked or ground grains. One hundred hens fed this way will cost perhaps forty cents per day for feed, and laying,sixty eggs per day at an average price near thirty cents a dozen will give you a nice clean profit of one dollar per" day. These advertisers who get hundreds of dollars a day from so many hens do not include the cost of the ads, etc. The owner of the great Crystal White Peggy might honestly advertise that he made $\$ 1,000$ a day from one hen, considering the price he got from the foreigner for five of the hen's descendents, but he does not seem to be in that business.

A good rule for feeding is always to feed just about what the flock will nicely clean up in the course of the day. 
Another idea I lave gotten rid of is that of feeding skim mill to the chickens as a beverage. It does not amount to anything as an ege producer, and ny observation has shown me that the chickens will fill up on it to the exclusion of the foods they ought to have. As a liquid for wetting a mash, it is all right.

\section{EGG PRESERVATION.}

The poultry jommals are crowded with adrertisements of persons anxious to separate you from your money. or a part of it, by telling you for one dollar, ten dimes, or one humdred copper cents, how to preserve eggs and hold them for higher prices. An! wholesale drug company will be able to supply you with soda silicati commonly called liquid-glass and water-glass, at a price of about is cents per gallon (about $1:$ pounds). this is cliluted with an equal quantity of water. If eggs are dipped twice in this solution they will keep at least a year under ordinary conditions. This is the much adrertised recipe, and as it cost me nothing to figure it out, it costs you nothing here, but it sares you that hundred cents. By dipping is meant wetting egg in the above solution the day it is gathered and again dipping egg the next day the second time-this giving a coating of liquid glass, which prevents evaporation.

\section{INCUBATION.}

I am going to tell you something about incubation that no paper or incubator num has ever been able to tell you, although you see the question persistently asked, "Why do my chicks die in the shell?" Did you ever 
figure it out? I did, from reading the earlier articles in this book on food, eggs, etc.

There is the making of a chicken in the yolk of an egg:

How? By the constituents of the "yellow" and "white" and shell.

Through the influence of incubating heat.

A yolk is not alive with blood, or flesh, or bones, or feathers before it is incubated and hatched. What constitutes incubating or hatching-? Simply this: Heatinga certain degree and duration of it-sets in motion the "functions" of the chemical "organic" compounds which compose eg"yolk, as winding sets in motion the mechanism of a clock; and the egg. unalive, begins to brcathe. Ies, sir, begins to "breathe."

The "incubated" egg actually inhales oxygen and exhales carbonic acid gas as plants and animals do: and perspires vapor or moisture through its shell-coat as we do through our skin.

Day by day, the activity or motion of the yolk-chemicals increases and "attracts" the chemicals of the white and of the shell-and behold-a chick.

Why hatched? Because heat motion helped to start motion of a given kind. called breathing, inside of the egg shell. If that heat, or the lack or excess of some degrees of it. had started another kind of motion. called fermentation, inside of that same egg shell-as often happens-the outcome or product would have been rot instead of a chicli.

The heat started "function" or breathing in the eg.' yolk, and heat awakened or wound up the "still" mechan- 
ism of organized matter, thereby setting in motion certain physical elements which moisture and minerals and albumenoids maintained until blood and flesh became "animated" with instinct-another form of motion-which led its owner to fracture the egg shell that the chicken might wiggle out into surroundings containing greater stores of heat, moisture, minerals, albumenoids, light, and joys or sorrows, according to the wisdom in brooding possessed by its owner.

Now. to sum it all up, it is "oxidation" which gives life to the chick in its shell, and oxidation which thins the shell progressively until the chicken can escape at the right time into an atmosphere where there is more oxygen and less heat.

Do you understand now why your chicks die in the shell?

\section{Lack of oxygen.}

I have never seen an incubator that was anywhere near perfect in supplying sufficient fresh air to ozygenize the poor little cuss struggling in that warm egg shell. Incubator manufactorers especially make matters worse by telling their customers to set up the machines in a cellar where the temperature is pretty nearly steady. Now did you ever see a cellar where the supply of oxygen was such that you would like to spend a large part of your time in it? Never. An incubator properly constructed should admit plenty of air; there should be a row of warm pipes beneath the egg tray as well as the heat above the tray, and the thermometer ought to be suspended even with the eggs. Outside temperature ought not to influence an incubator very much 
if it is properly insulated-say it be as well insulated as our fireless cookers. Think over this, build one and grow prosperous.

The brooders are far worse than the incubators as at present constructed. The idea of keeping a chicken breathing such hot air is pretty nearly a crime. When hen=brooded their heads are "out of doors" and their little bodies tucked indoors. If you want a fireless, or oil saving brooder, why not use soap stones for heaters? That would be more humane than nothing in the way of heat.

That's all about chickens, and egg production, and incubation. Remember you save the price of this book many times over in the saving effected by removing beef scraps, aifalfa meal, bone meal, etc., from the daily menu, besides learning how to preserve eggs with "water-glass." Feed as instructed and you will have eggs all the year round and at the minimum expense for feed and labor.

As an illustration of the ignorance prevailing where the composition of food is concerned-I wrote Mr. Chas. A. Cyphers, designer of many incubators, and many attachments for use thereon. He is also President and actual head of the mammoth chicken park known as the Model Poultry Farm, near Buffalo, N. Y. In reply to my question as to the relative value of green foods in winter, his response, to be brief was: "Mangels are as good as anything." Now, that reply reflects the lack of attention this most important matter receives at the hands of socalled practical poultrymen. If you will refer back a 
A TREATISE ON FOODS.

few pages to "a handy table of the various foods," you will see Mangels at the bottom of the list-about ninety per cent water and no nourishment at all. You can draw your own conclusions.

\section{THE FINAL WORD.}

This work covers, of course, many foods not strictly on the hen dietary; however, the book being of an educational nature, and destined (I hope) to reach thousands of homes where a food analysis was never before seen, it was thought only proper that the everyday food substances be given attention, for every child and every parent ought to know something of the origin and uses of the foods they daily consume.

(THE END.) 


\section{A TREATISE ON FOOD AND EGG PRODUCTION}
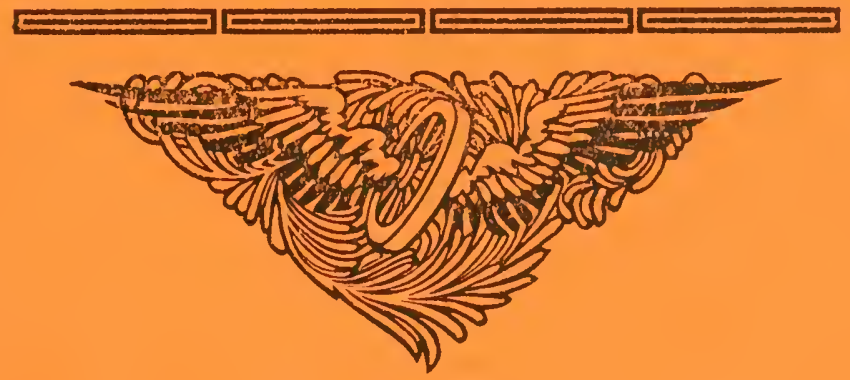

By Frederick Kellaey 





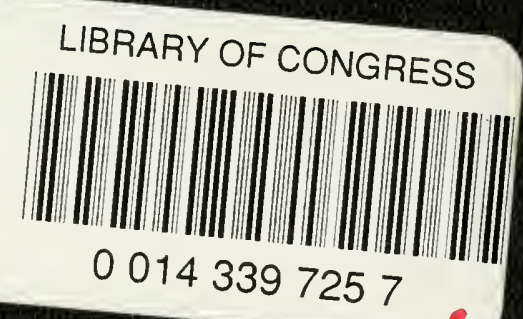

